\title{
Test Results for CSTR Test 3
}

D. D. Lee and J. L. Collins 


\section{DOCUMENT AVAILABILITY}

Reports produced after January 1, 1996, are generally available free via the U.S. Department of Energy (DOE) Information Bridge:

Web site: http://www.osti.gov/bridge

Reports produced before January 1,1996, may be purchased by members of the public from the following source:

National Technical Information Service

5285 Port Royal Road

Springfield, VA 22161

Telephone: 703-605-6000 (1-800-553-6847)

TDD: $703-487-4639$

Fax: 703-605-6900

E-mail:info@ntis.fedworld.gov

Web site: http://www.ntis.gov/support/ordernowabout.htm

Reports are available to DOE employees, DOE contractors, Energy Technology Data Exchange (ETDE) representatives, and International Nuclear Information System (INIS) representatives from the following source:

Office of Scientific and Technical Information

P.O. Box 62

Oak Ridge, TN 37831

Telephone: 865-576-8401

Fax: 865-576-5728

E-mail:reports@adonis.osti.gov

Web si te: http://www.osti.gov/contact.html

This report was prepared as an account of work sponsored by an agency of the United States Government. Neither the United States government nor any agency thereof, nor any of their employees, makes any warranty, express or implied, or assumes any legal liability or responsibility for the accuracy, completeness, or usefulness of any information, apparatus, product, or process disclosed, or represents that its use would not infringe privately owned rights. Reference herein to any specific commercial product, process, or service by trade name, trademark, manufacturer, or otherwise, does not necessarily constitute or imply its endorsement, recommendation, or favoring by the United States Government or any agency thereof. The views and opinions of authors expressed herein do not necessarily state or reflect those of the United States Government or any agency thereof. 
Chemical Technology Division

\title{
Test Results for CSTR Test 3
}

\author{
D. D. Lee and J. L. Collins
}

Date Published: October 2000

\author{
Prepared by \\ OAK RIDGE NATIONAL LABORATORY \\ P.O. Box 2008 \\ Oak Ridge, Tennessee 37831-6285 \\ managed by \\ UT-BATTELLE, LLC \\ for the \\ U.S. DEPARTMENT OF ENERGY \\ under contract DE-AC05-00OR22725
}





\section{CONTENTS}

LIST OF FIGURES

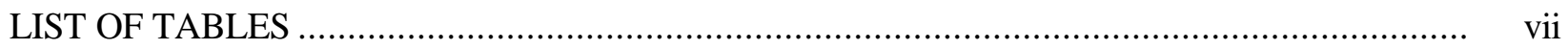

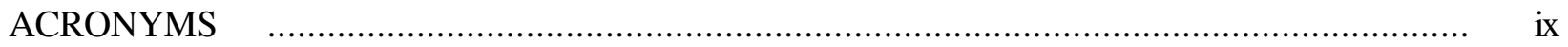

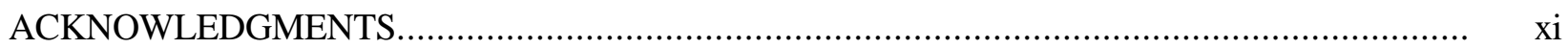

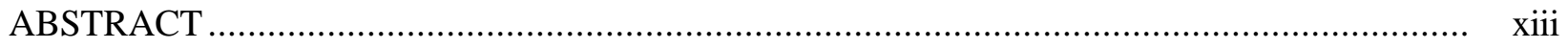

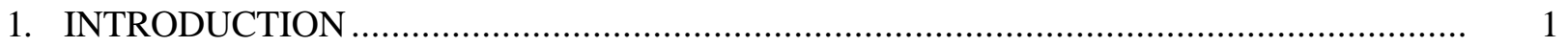

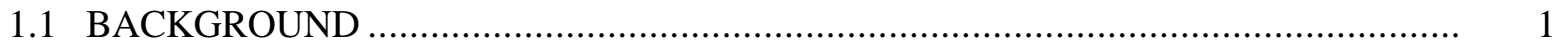

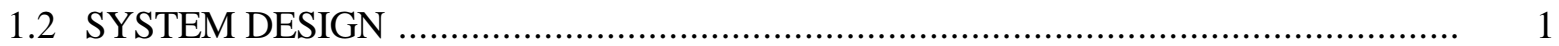

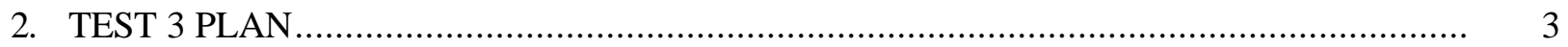

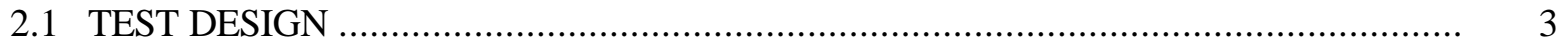

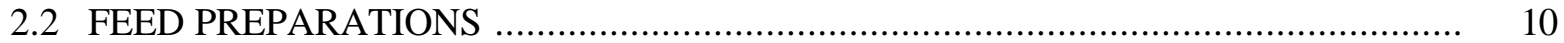

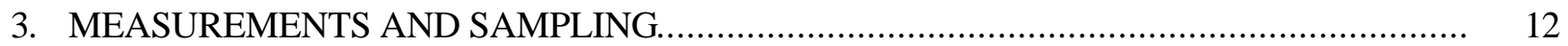

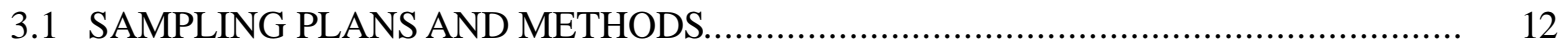

3.2 MEASURING AND TEST EQUIPMENT ……………........................................ 13

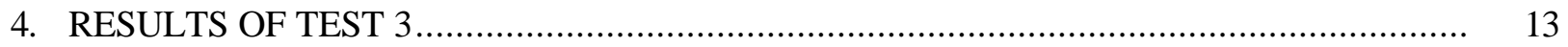

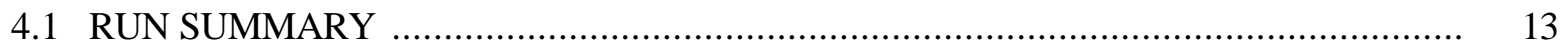

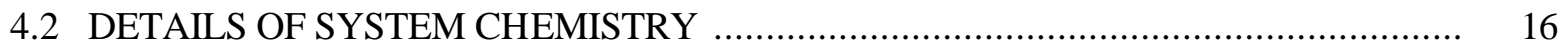

4.2.1 Cesium Decontamination of Test 3 Salt Feed................................................... 16

4.2.2 Strontium Decontamination of Test 3 Salt Feed................................................. 17

4.2.3 Uranium Decontamination of Test 3 Salt Feed.................................................. 19

4.2.4 HPLC Analyses for TPB Decomposition Products............................................... 22

4.2.5 ICP-AES Analyses for Potassium and Boron ...................................................... 22

4.2.6 Material Balances................................................................................ 25

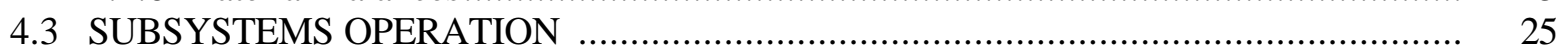

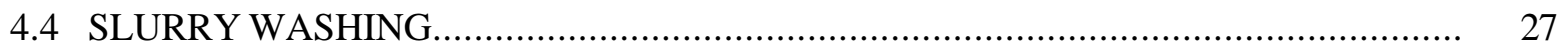

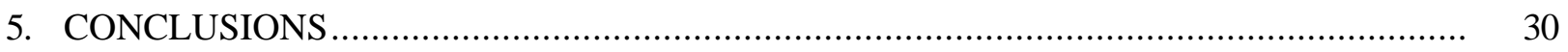

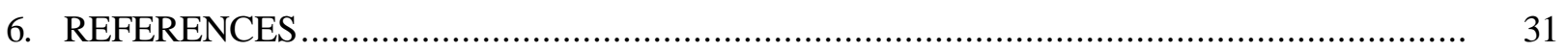





\section{LIST OF FIGURES}

Figure $\quad$ Page

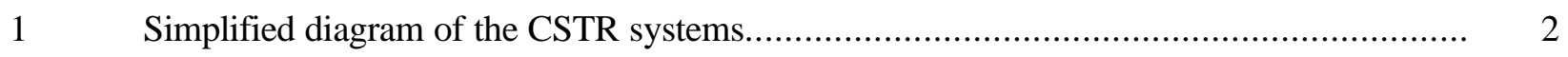

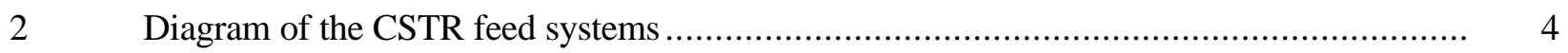

$3 \quad$ Redesigned slurry concentration filter system ................................................ 5

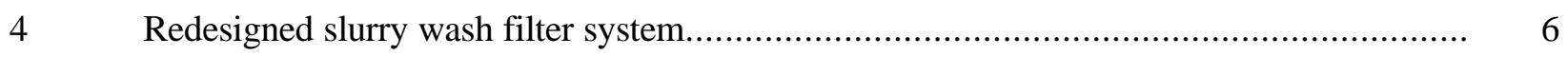

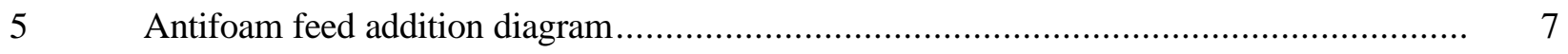

$6 \quad$ Flowsheet for the benzene monitoring system ............................................... 8

$7 \quad$ Valves and piping for the benzene monitoring system......................................... 9

$8 \quad$ Foam produced from a potassium TPB slurry at an agitator speed of $1200 \mathrm{rpm}$ without

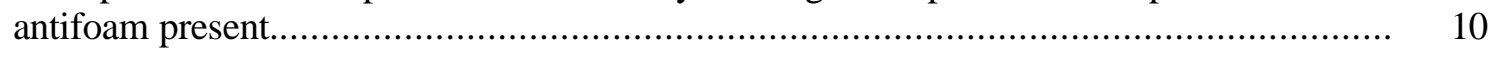

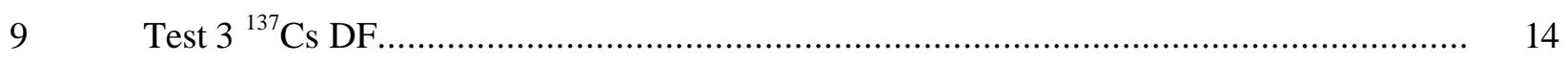

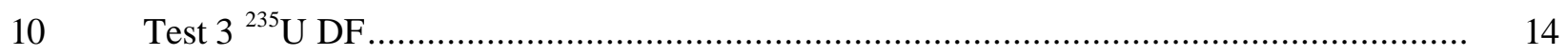

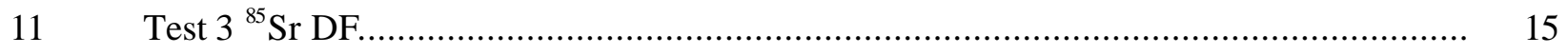

$12 \quad{ }^{137}$ Cs after CSTR 1, CSTR 2, and in the concentrate filtrate during Test 3...................... 16

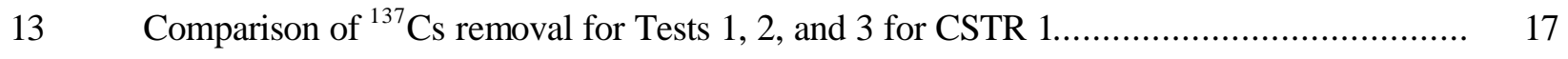

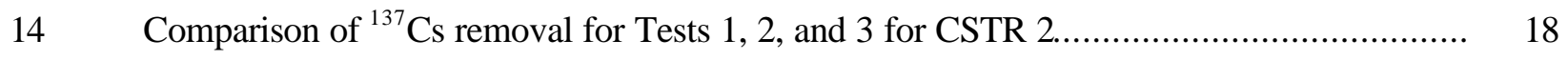

15 Comparison of ${ }^{137} \mathrm{Cs}$ removal for Tests 1,2 , and 3 for concentrate filtrate ........................ 18

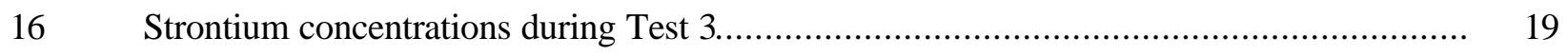

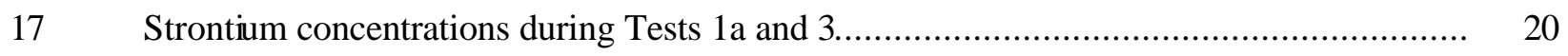

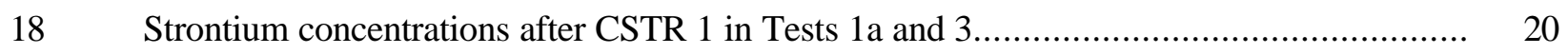

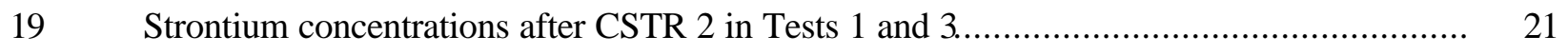

20 Strontium concentrations in concentrate filtrate in Tests 1a and 3............................ 21

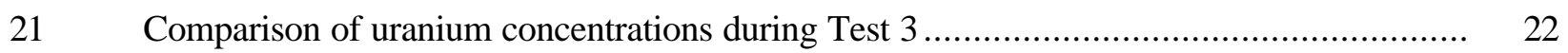

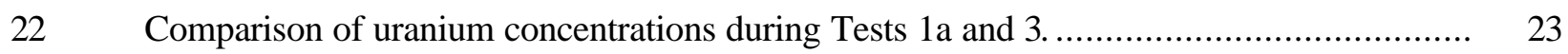

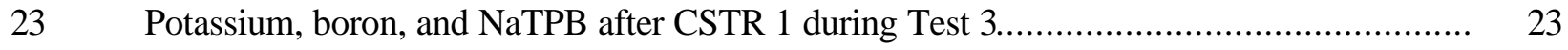


24 Potassium, boron, and NaTPB after CSTR 2 during Test 3.................................. 24

25 Potassium, boron, and NaTPB in concentrate filtrate during Test 3.............................. 24

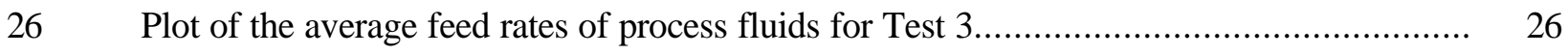

27 Plot of the cumulative feed totals for materials fed to CSTR 1 during Test $3 \ldots \ldots \ldots \ldots \ldots \ldots . . . . . . . .26$

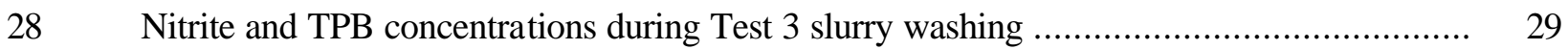




\section{LIST OF TABLES}

Table

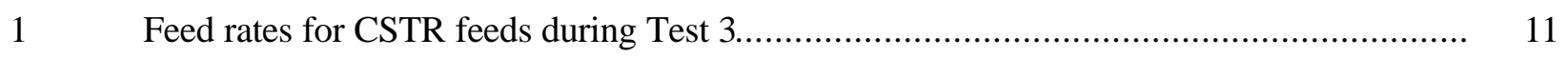

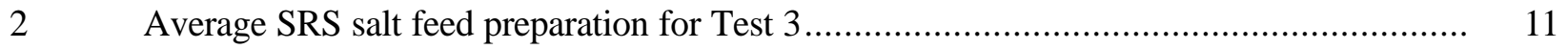

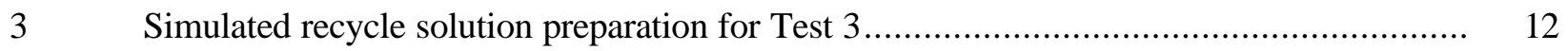

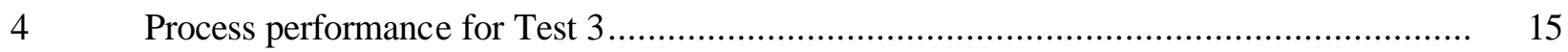

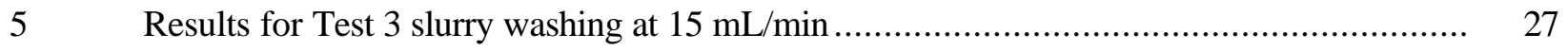

$6 \quad$ NaTPB recovery in the slurry washing process in CSTR tests .................................... 30 



\section{ACRONYMS}

CSTR continuous-flow stirred-tank reactor

DF decontamination factor

FTIR Fourier transfer InfraRed analyzer

HLW high-level waste

HPLC high-performance liquid chromatography

ICP-AES inductively coupled plasma-atomic emission spectroscopy

KTPB potassium tetraphenylborate

MST monosodium titanate

NaTPB sodium tetraphenylborate

ORNL Oak Ridge National Laboratory

PBs $\quad 1 \mathrm{~PB}, 2 \mathrm{~PB}$, and $3 \mathrm{~PB}$ decomposition products of $\mathrm{TPB}$

RMAL Radioactive Materials Analytical Laboratory

SCT Slurry Concentrating Tank

SPP Salt Waste Processing Program

SRS Savannah River Site

SS Stainless Steel

SWT Slurry Washing Tank

TPB tetraphenylborate

WAC waste acceptance criteria

3PB triphenylborane

2PB diphenylborinic acid

1PB phenylboronic acid 



\section{ACKNOWLEDGMENTS}

This study was sponsored by the Tanks Focus Area of DOE's EM-50 under contract DE-AC0500OR22725 with UT-BATTELLE, LLC.

The authors wish to thank their colleagues at the Westinghouse Savannah River Company and Savannah River Technology Center for the invaluable assistance they provided in ensuring that the 20-L CSTR Demonstration Program was a success. In addition to participating in the actual tests, the Savannah River Salt Waste Processing Program (SPP) Team provided excellent design, operational, and chemistry guidance. Some of the many key contributors were (in alphabetical order) Mark Barnes, Seth Campbell, Joe Carter, Hank Elder, Sam Fink, Jim Firth, Rick Fowler, Harry Harmon, Roy Jacobs, Rocci Norcia (the Control Company), Reid Peterson, Michael Poirier, Ken Rueter, Steve Schlahta, Tony Tipton, and Walter Tamosaitis.

The efforts of the ORNL staff are also greatly appreciated. Kim Anderson, Bill Chase, Jim Hewitt, Rodney Hunt, Tim Kent, Steve Richardson, Jim Travis, and Betty Evans of the Chemical Technology Division participated in preparing and conducting the tests. Max Cronan, Greg Knox, and other members of the Plant and Equipment Division, as well as Vern McClain, Don Raby, and members of the Instrumentation and Controls Division, did an excellent job in the construction and installation of the experimental equipment in the hot cells. John Keller, Joe Giaquinto, and the technicians at the Radioactive Materials Analysis Laboratory conducted the hundreds of required analyses in a timely manner. John Slaten and the staff of Radiation Protection provided excellent support through the long days and nights of continuous operations. The authors also appreciate the efforts of Richard Shoun for his guidance on safety-related matters and the ALARA Plan, Bob Jubin and Phil McGinnis for their managerial help and guidance, Roger Jones for his assistance with the QA plan, Don Coffey for his coordination of the waste disposal activities, and Beulah Brock for her considerable help and patience in dealing with the large volume of paperwork that this project entailed. 



\begin{abstract}
The goal of the Savannah River Salt Waste Processing Program (SPP) is to evaluate and select the most effective technology for the treatment of the high-level waste salt solutions currently being stored in underground storage tanks at the U.S. Department of Energy Savannah River Site (SRS) in Aiken, South Carolina. One of the three technologies currently being developed for this application is the Small-Tank Tetraphenylborate Process (STTP). This process uses sodium tetraphenylborate (NaTPB) to precipitate and remove radioactive cesium from the waste and monosodium titanate (MST) to sorb and remove radioactive strontium and actinides. Oak Ridge National Laboratory is demonstrating this process at the 1:4000 scale using a 20-L capacity continuous-flow stirred-tank reactor (CSTR) system. Since March 1999, three operating campaigns of the 20-L CSTR have been conducted. The ultimate goal is to verify that this process, under certain extremes of operating conditions, can meet the minimum treatment criteria necessary for processing and disposal at the Savannah River Saltstone Facility. The waste acceptance criteria (WAC) for ${ }^{137} \mathrm{Cs},{ }^{90} \mathrm{Sr}$, and total actinides are $<40 \mathrm{nCi} / \mathrm{g},<40 \mathrm{nCi} / \mathrm{g}$, and $<18 \mathrm{nCi} / \mathrm{g}$, respectively. However, to allow for changes in process conditions, SPP is seeking a level of treatment that is about $50 \%$ of the WAC. The bounding separation goals for ${ }^{137} \mathrm{Cs}$ and ${ }^{90} \mathrm{Sr}$ are to obtain decontamination factors (DFs) of 40,000 (99.998\% removal) and 26 (96.15\% removal), respectively. The $\mathrm{DF}$ is defined as the concentration of contaminant in the waste divided by the concentration of contaminant in the effluent stream.

Tests 1 and 2 were conducted in June and July 1999, and the results are documented in ORNL/TM-1999/234. These initial tests, using simulants traced with radioactive materials, verified that the STTP process could achieve the necessary cesium, strontium, and actinide decontamination under standard operating conditions, with and without the recovery and recycle of the excess sodium tetraphenylborate (NaTPB) that was not precipitated with potassium and cesium. TPB decomposition, the major side reaction of the process, did not occur in Test 2 despite the addition of materials (synthetic sludge and modified Enhanced Comprehensive Catalyst) that were known to cause TPB to degrade.

Test 3 was a 72-h demonstration that was conducted August 2000. The objectives were to examine the effectiveness of an improved antifoam (IITB52) in minimizing foam formation and to determine if its presence had a damaging effect on the removal of ${ }^{137} \mathrm{Cs},{ }^{85} \mathrm{Sr}$, and ${ }^{235} \mathrm{U}$ from simulated waste. To more aggressively test the antifoam, the slurry in each vessel was mixed at 1200 to $1250 \mathrm{rpm}$ while maintaining the temperature at $25^{\circ} \mathrm{C}$. This rate of mixing was found to cause heavy foam formation in a control test that was conducted prior to Test 3 . No evidence of excessive foam formation was noted in Test 3. Excessive foam formation would have been indicated by the presence of foam in the analytical samples of slurries taken, by the presence of foam in the clear plastic slurry transfer lines between the vessels, by significant changes in the level probe readings in process vessels, and by large changes in the slurry density measurements in the slurry concentration system.

The decontamination goal of obtaining a decontamination factor (DF) o 40,000 or $99.998 \%$ removal was exceeded in all process vessels. $\mathrm{A} \mathrm{DF}_{\mathrm{Cs}}$ of 40,000 was obtained in $14 \mathrm{~h}$ in CSTR 1 and afterward ranged between 41,000 and 270,000. It took about $32 \mathrm{~h}$ for the DF to reach 40,000 in CSTR 2, and for the remainder of the test, the DF ranged from 49,000 to 77,000. $\mathrm{A} \mathrm{DF}_{\mathrm{Cs}}$ of 37,000 was obtained in the slurry concentrating tank (SCT) in about $32 \mathrm{~h}$. It subsequently fluctuated between 21,000 and 59,000 and was the highest at the end of the test.

No impact of the IITB52 on the sorption of strontium and uranium by the MST was noted. A $\mathrm{DF}_{\mathrm{Sr}}$ of 26 was needed to reach the WAC standard for saltstone. A DF of 30 was obtained for strontium in the SCT in about $24 \mathrm{~h}$, and near the end of the test, it was 100. A DF of 5 for uranium in the SCT was obtained at the end of the test. This is indicative that the other actinides neptunium and plutonium would have DFs that would have met the WAC for saltstone.

At the end of Test 3, the concentrated slurry in the concentrating system was transferred to the Slurry Washing Tank and washed with deionized water to recover unutilized NaTPB. IITB52 was added to the tank at a rate of $0.00312 \mathrm{~mL} / \mathrm{min}$. Because of the method of starting Test 3 in which the process
\end{abstract}


vessels were first filled with the $4.7 \mathrm{M} \mathrm{Na}^{+}$salt feed, a large fraction of the TPB added was precipitated as potassium tetraphenylborate (KTPB), leaving only $0.33 \mathrm{~mol}$ of excess TPB in the slurry concentrating system available for recovery during water washing. The collected washwater had a concentration of $0.0033 \mathrm{~mol} / \mathrm{L}$ TPB $(0.095 \mathrm{~mol}$ TPB total), which was $29 \%$ of the available TPB. This amount was greater than the amount recovered in Test 1a, in which only $12 \%$ of the available TPB was recovered and no IITB52 was used. This indicates that the antifoam did not interfere with the recovery of the precipitated NaTPB in this case. The higher mixing rate in Test 3 (1200 vs $600 \mathrm{rpm}$ ) may have aided in the larger fraction of TPB being recovered. 


\title{
TEST RESULTS FOR CSTR TEST 3
}

\author{
D. D. Lee and J. L. Collins
}

\section{INTRODUCTION}

\subsection{BACKGROUND}

The Small-Tank Tetraphenylborate Process (STTP) is one of three separations processes currently being examined by the Savannah River High-Level Waste (HLW) Salt Waste Processing Program (SPP) as an alternative to the In-Tank Precipitation Process for treatment of highly radioactive Savannah River Site (SRS) tank waste. The ultimate goal of the process is to decontaminate the SRS salt waste so that it meets the waste acceptance criteria (WAC) for processing and disposal at the Savannah River Saltstone Facility. The WAC for ${ }^{137} \mathrm{Cs},{ }^{90} \mathrm{Sr}$, and alpha are $<40 \mathrm{nCi} / \mathrm{g},<40 \mathrm{nCi} / \mathrm{g}$ and $<18 \mathrm{nCi} / \mathrm{g}$, respectively. However, to allow for changes in process conditions, the SPP is seeking a level of treatment that is about $50 \%$ of the WAC. Supernatants in high-OH SRS tanks that are $6.4 \mathrm{M}$ in $\mathrm{Na}^{+}$have cesium concentrations in the range of $0.000415 M$. Cesium concentrations for average SRS waste with the same $\mathrm{Na}^{+}$concentration are in the range of $0.000157 M$. The ${ }^{137} \mathrm{Cs}$ radioactivity level for these wastes are 1.1 and $0.41 \mathrm{Ci} / \mathrm{L}$, respectively.

A 1:4000-scale, 20-L continuous-flow stirred-tank reactor (CSTR) system was designed and fabricated at Oak Ridge National Laboratory (ORNL) for development of this process. The goal of the 20-L CSTR test program is to evaluate the performance of the 20-L CSTR system under conditions that simulate the anticipated full-scale operation of the system. The basic chemistry of the process makes use of tetraphenylborate (TPB) to remove cesium by precipitation and monosodium titanate (MST) to remove strontium and actinides (plutonium, neptunium, and uranium) by sorption. The CSTR system was to be operated in a contained and shielded hot cell environment to allow the use of radioactive materials.

Testing of the CSTR system would determine if this approach could (1) provide the cesium, strontium, and actinide separations needed for treatment of the SRS salt waste; (2) perform satisfactorily with an improved antifoam agent, and (3) perform satisfactorily while active decomposition of TPB was taking place with and without the recovery and recycle of unreacted TPB.

Test 1a (Tests 1b and 1c were not needed) and Test 2 were conducted in FY 1999 and met performance objectives in verifying that the required separations of cesium, strontium, and actinides could be provided by this process. ${ }^{1}$

The primary goal of Test 3 was to examine the effectiveness of an improved antifoam (IITB52) in minimizing foam formation and to determine if its presence in the TPB slurry had significant impact on cesium, strontium, and actinide removal performance. Test 3 was planned to be a single-pass, 80 -h test that provided about ten volume turnovers in the CSTRs. No sludge or catalyst was added to the salt feed, and the slurry solutions were maintained at $\sim 25^{\circ} \mathrm{C}$ during the test. ${ }^{2}$

\subsection{SYSTEM DESIGN}

The apparatus used in the test system was sized and designed to provide reliable data for scaleup to larger systems. Figure 1 shows a simplified process flowsheet for the system. All feeds are introduced into CSTR 1, and the degree of decontamination of the process stream in any vessel is always defined based on the feed to this reactor. Most of the precipitation of cesium takes place in CSTR 1. CSTR 2 provides additional residence time for a small amount of additional cesium precipitation to occur. However, the primary role of CSTR 2 in the process is to provide the required additional residence time needed for the MST to sorb the actinides present in the real waste. The test system, which is located in Hot Cell B, Building 4501, includes two CSTRs in series, each with a 15-L working volume; a slurry 


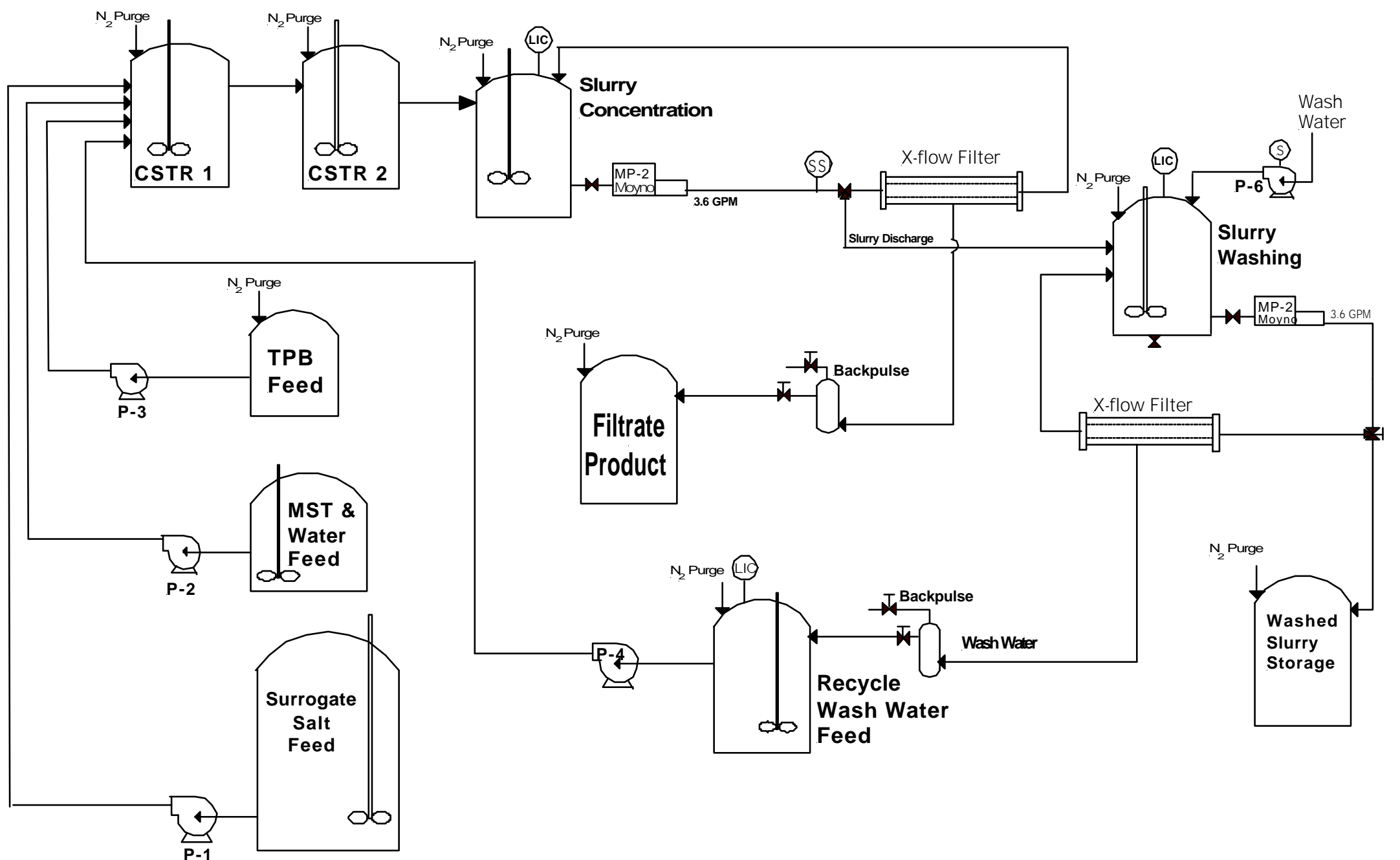

Fig. 1. Simplified diagram of the CSTR systems. 
concentration tank with a cross-flow filter to concentrate the slurry; a concentrated-slurry washing tank with a cross-flow filter; and various tanks and pumps to integrate the operation. Two 55-gal feed tanks with mixing systems were located in Hot Cell A.

After Test 2 was concluded, plans were developed for making needed improvements to the CSTR system. Modifications were needed to provide improved control systems and data collection, vessel offgas monitoring for benzene, improved level monitoring, and improved antifoam feed capability. In more detail, the CSTR modification in Cell B involved the following:

1. Rerouting some of the stainless steel piping to change the flow configuration.

2. Installing eight electric valves for improved cross-flow filter backpulse systems. (Six were new, and two replaced manual valves.)

3. Replacing two three-way manual valves with five-way electric valves to improve the ability to direct slurry flow.

4. Installing four pressure transducers and two flow transmitters (part of the improved backpulse system).

5. Installing/retrofitting electrical/instrument pigtail connections on cables for valves and instruments (for ease of connection and removal during cell entries) and installing signal cables for new valves and instruments (the four pressure transducers and two flow transmitters).

6. Installing new flex tubing and replacing some flex tubing with hard-piped stainless steel (SS) tubing on the CSTRs and filter systems.

7. Installing a benzene monitoring system to monitor the off-gas from CSTR 1, CSTR 2, the Slurry Concentrating Tank (SCT), and the Slurry Wash Tank (SWT). This included 4 GASMET Fourier transform infrared (FTIR) analyzers; 4 pumps; 8 mass-flow meters; 12 solenoid valves with appropriate plumbing; 4 liquid traps; and necessary tubing, heat tracing, thermocouples, and electrical wiring.

8. Installing new antifoam delivery systems to the two CSTRs and to the SCT and SWT.

9. Installing a new level probe in the concentrate tank identical to the one in the SWT and a new level probe in CSTR 1 (which can be used as a backup for the either of the other two level probes).

10. Transferring the simulated salt feed and washed slurry concentrate equipment from Hot Cell A to Hot Cell C.

Figures 2-7 provide the updated flowsheets for the TPB process test system in Hot Cell B. Figure 2 shows the CSTR feed systems; Fig. 3, the slurry concentrate system; and Fig. 4, the slurry wash system. Figure 5 shows the antifoam feed system, and Figs. 6 and 7 show the CSTR benzene monitoring flowsheets.

\section{TEST 3 PLAN}

\subsection{TEST DESIGN}

The primary goal of Test 3 was to examine the effectiveness of an improved antifoam (IITB52) in minimizing foam formation and to determine if its presence in the TPB slurry had a deleterious effect on the decontamination factors (DFs) of cesium, strontium and uranium. Test 3 was planned to be a singlepass (no recycle of recovered TPB), 80-h test that provided about ten volume turnovers in the CSTRs. No sludge or catalyst was added to the salt feed, and the slurry solutions were maintained at $\sim 25^{\circ} \mathrm{C}$ during the test. IITB52 is a water-soluble liquid with a density of $1.01 \mathrm{~g} / \mathrm{mL}$. It was pumped continuously with syringe pumps to the CSTRs and SCT to limit foam formation. The concentration of IITB52 in the salt feed slurry was maintained at 50 ppmv (parts per million by volume) in the CSTRs and 100 ppmv in the SCT. The CSTRs were filled with diluted salt feed $\left(4.7 M \mathrm{Na}^{+}\right)$at the start of the test, and about $3 \mathrm{~L}$ was added to the SCT.

An agitator speed of $1200 \mathrm{rpm}$ was chosen for the test based on the results of a preliminary test performed with a slurry of KTPB. A photo of the foam generated during this test is shown in Fig. 8. 


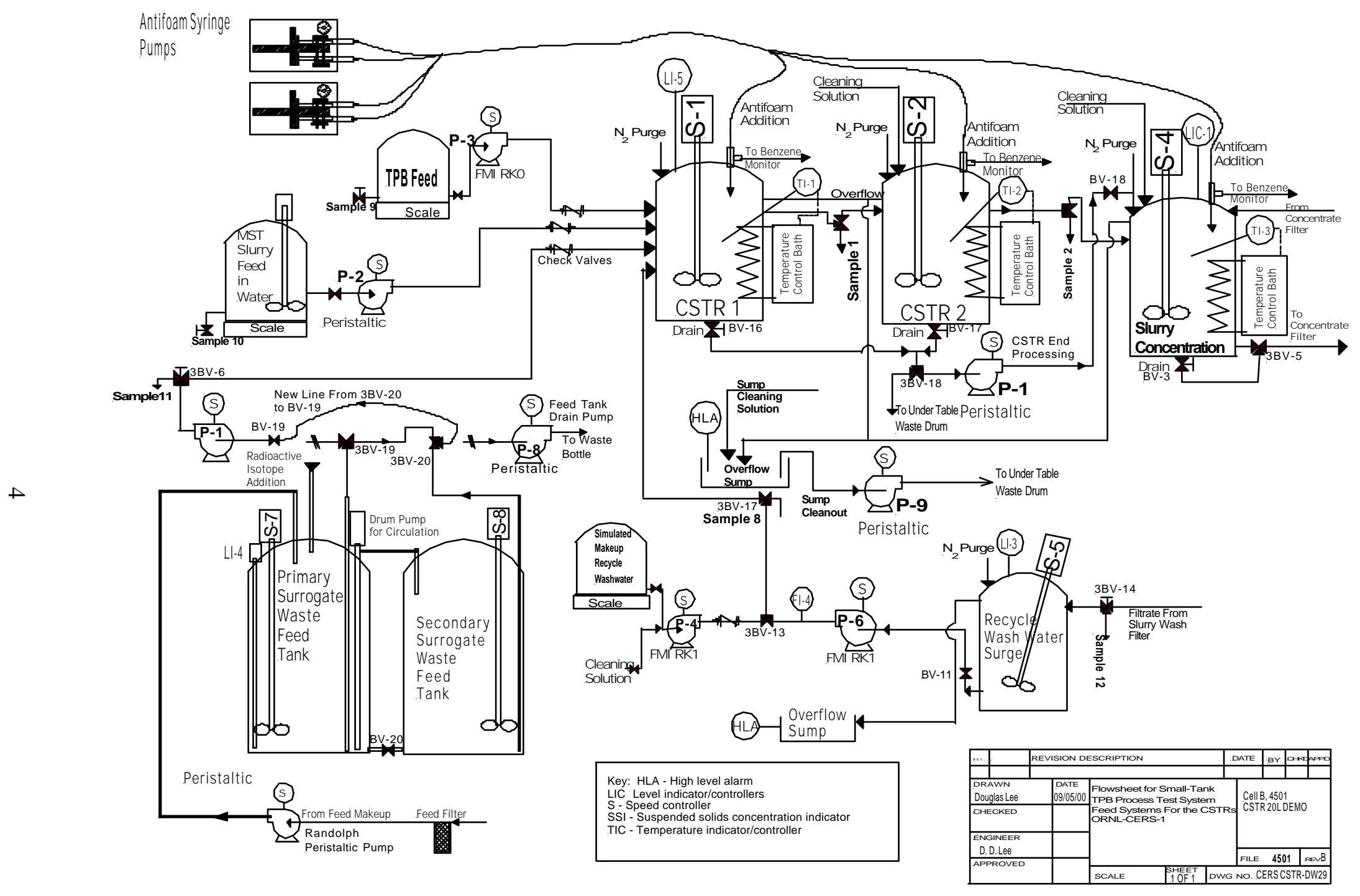

Fig. 2. Diagram of the CSTR feed systems. 


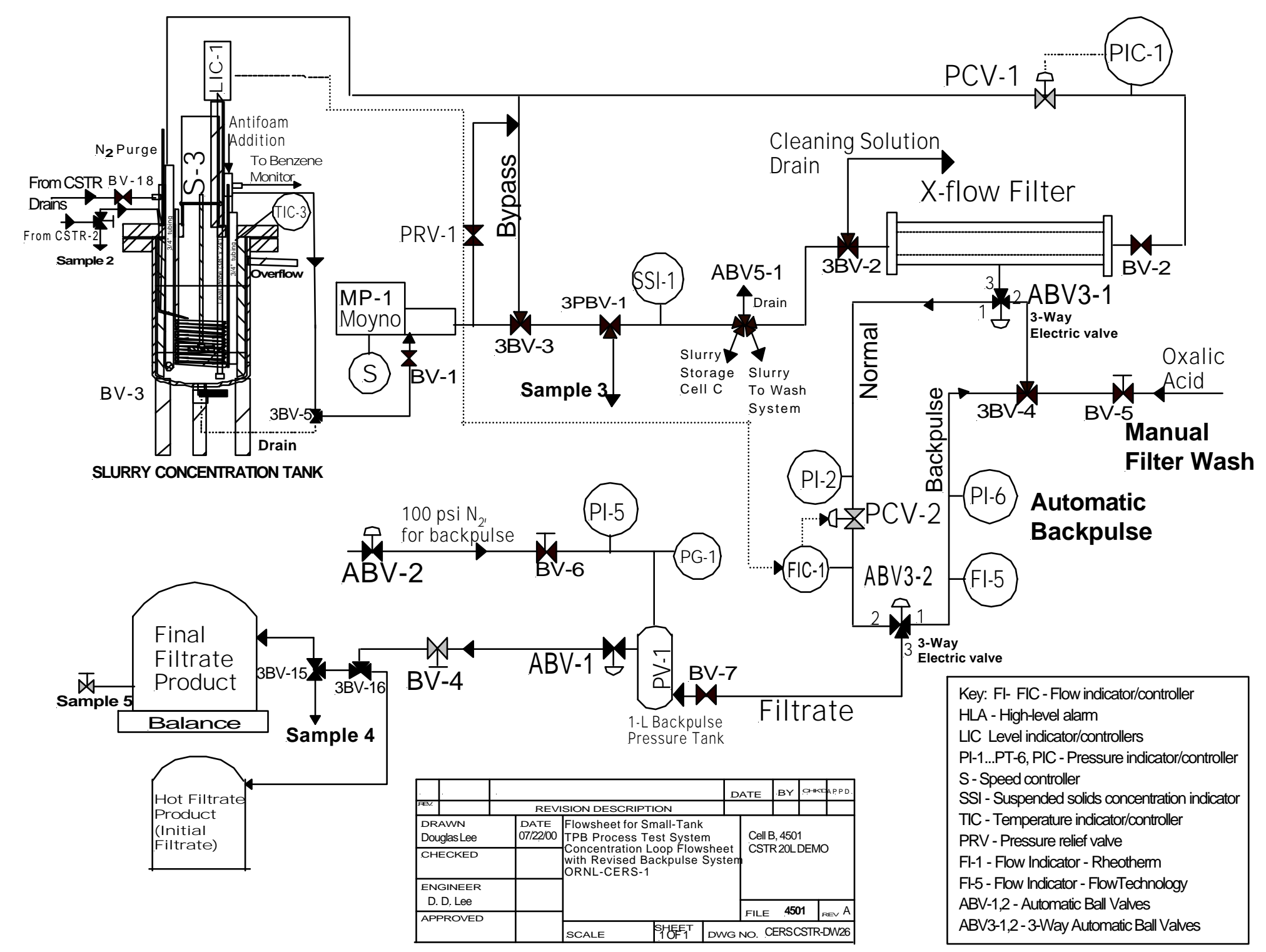

Fig. 3. Redesigned slurry concentration filter system. 


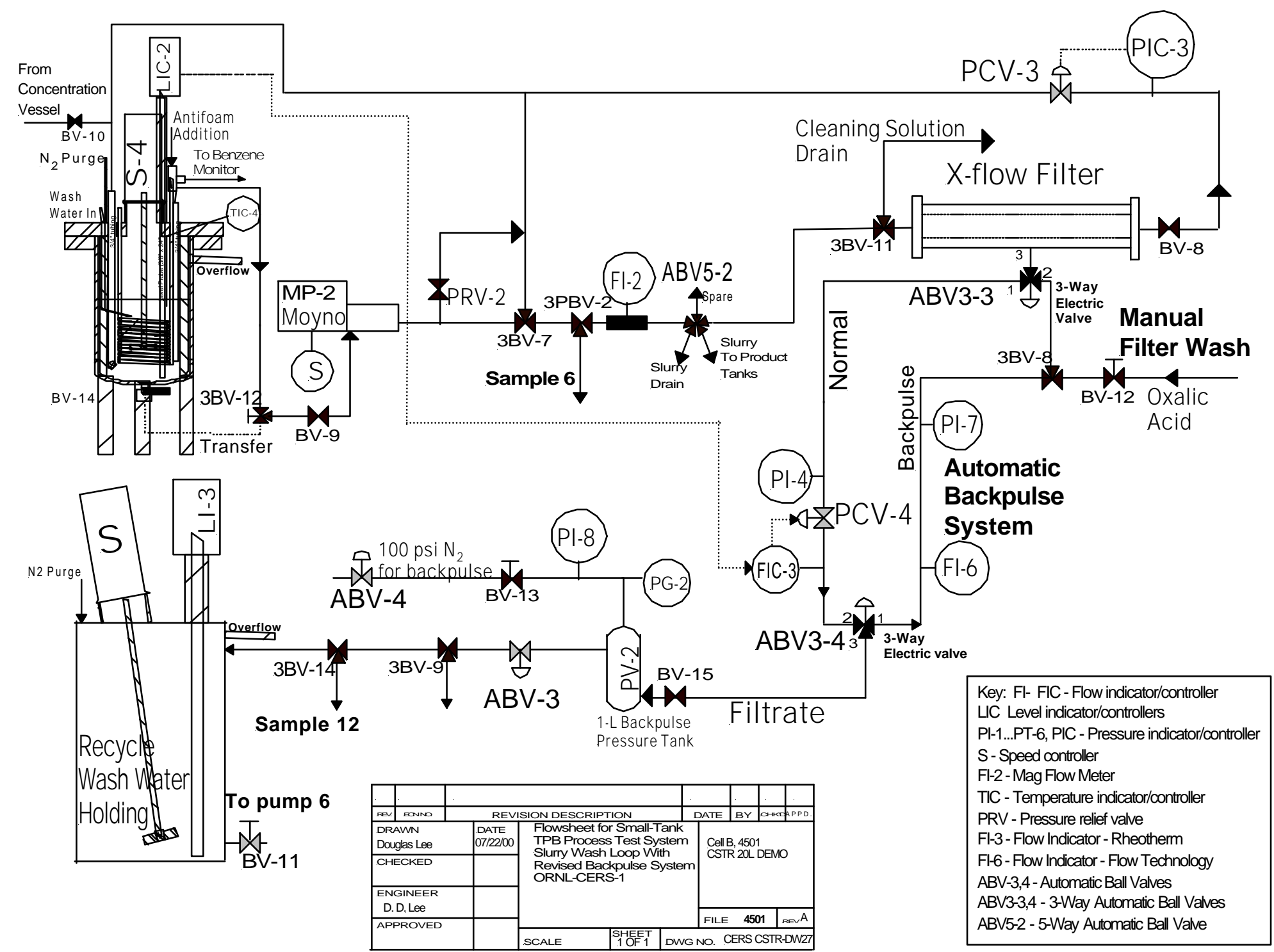

Fig. 4. Redesigned slurry wash filter system. 


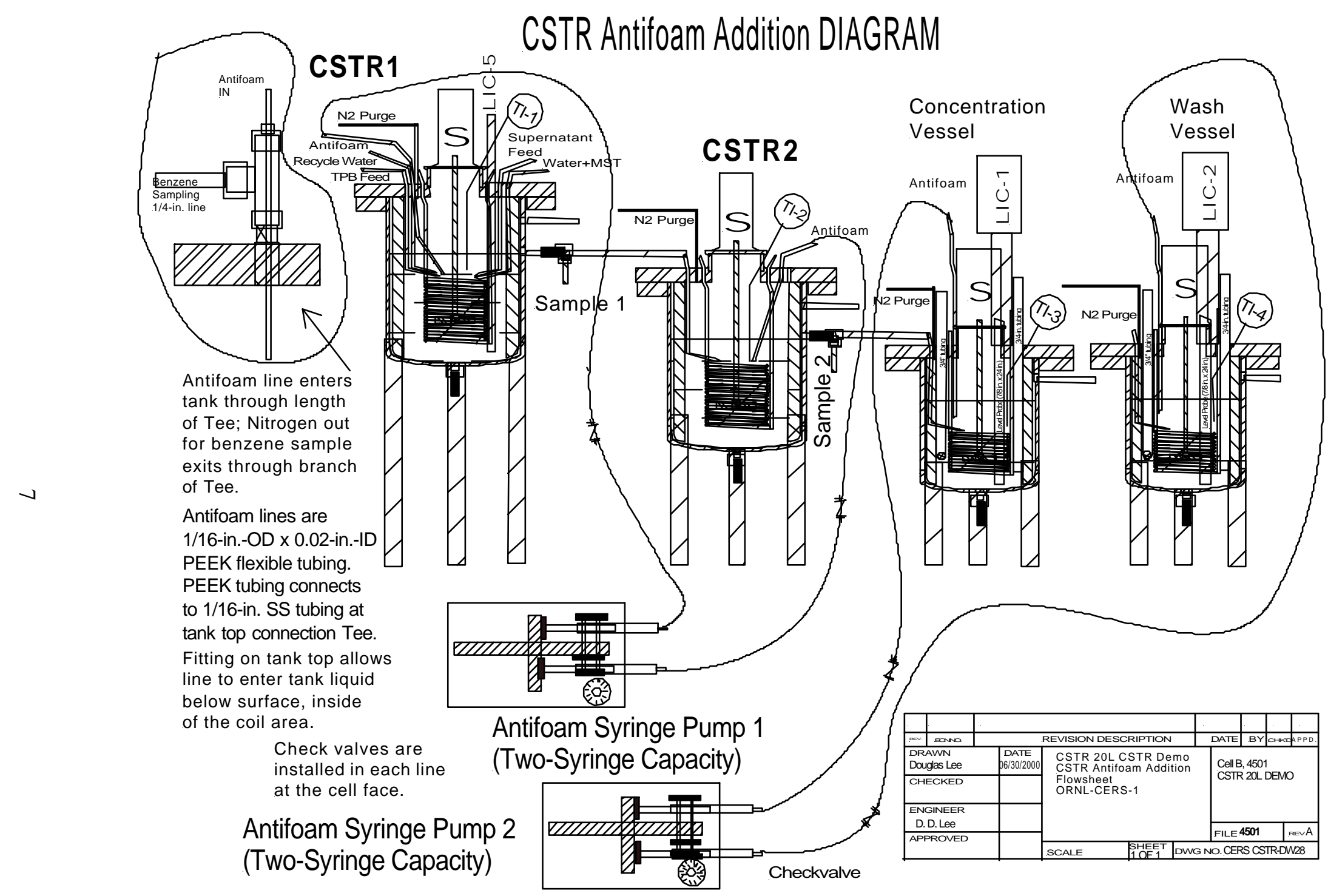

Fig. 5. Antifoam feed addition diagram. 


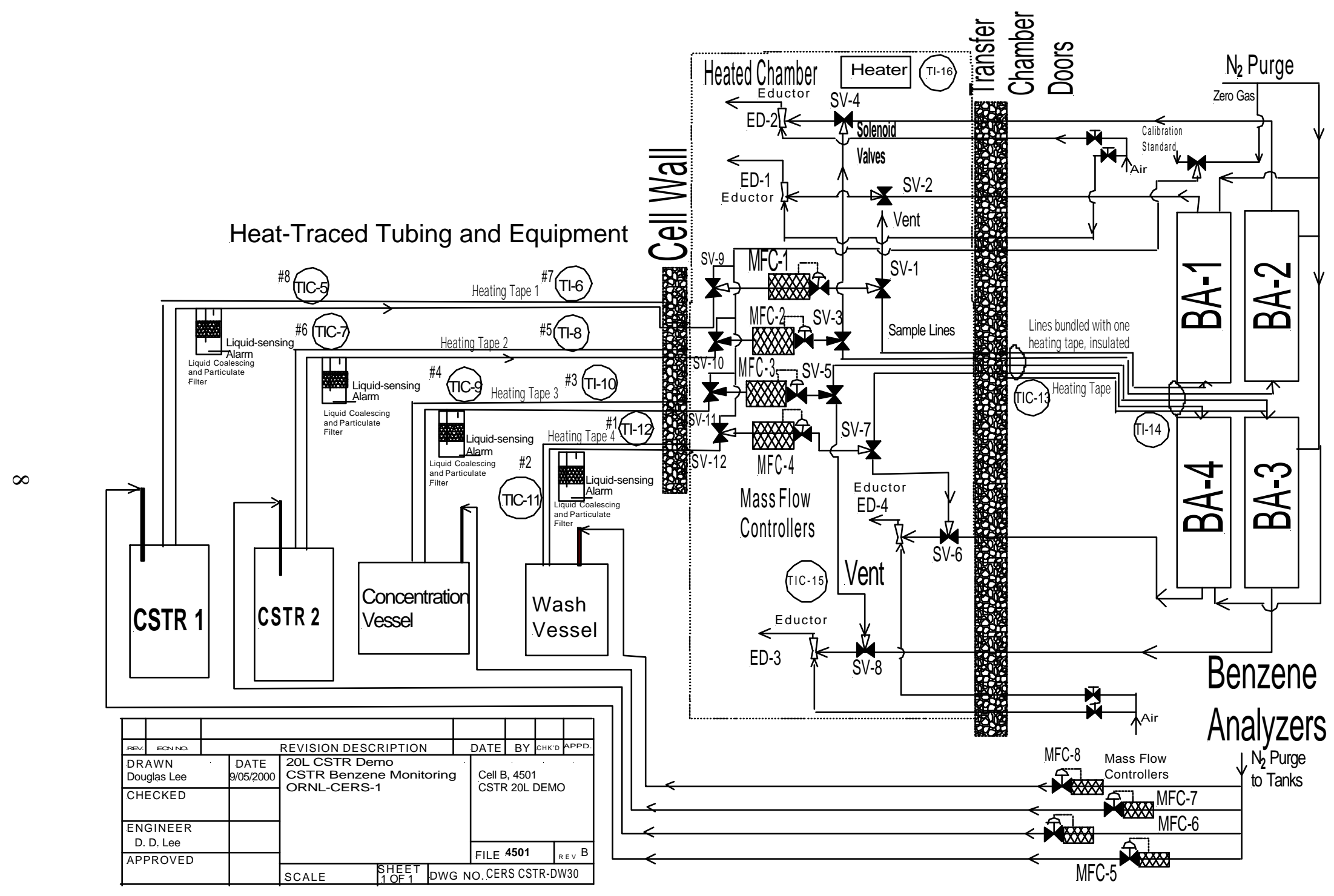

Fig. 6. Flowsheet for the benzene monitoring system. 
Cell Transfer Compartment

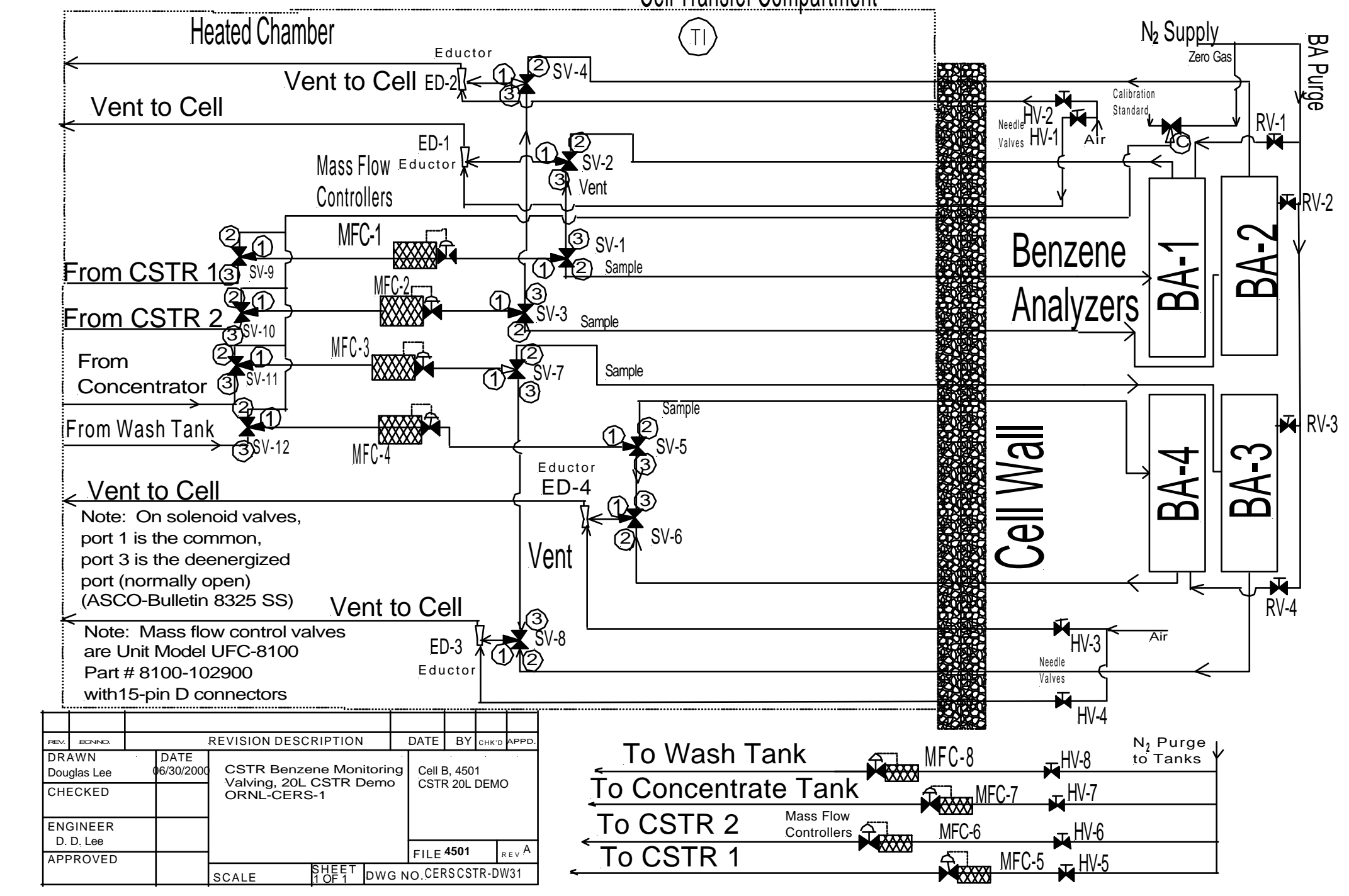

Fig. 7. Valves and piping for the benzene monitoring system. 


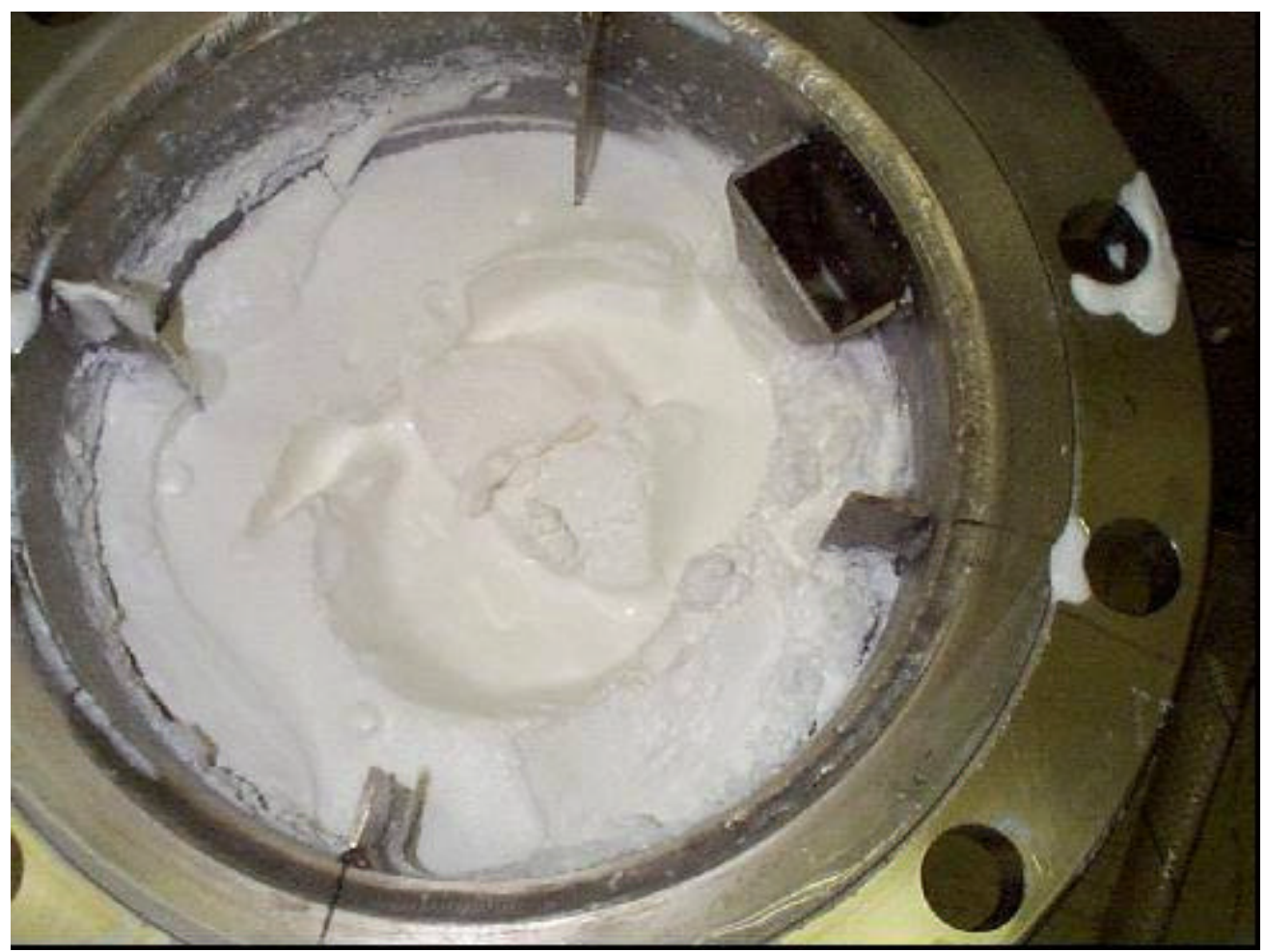

Fig. 8. Foam produced from a potassium TPB slurry at an agitator speed of $1200 \mathrm{rpm}$ without antifoam present. (Normal operations at $600 \mathrm{rpm}$ produced very little foam.)

\subsection{FEED PREPARATIONS}

The procedures and materials for feed preparation are given in CERS/SR/TPB/005. ${ }^{3}$ Table 1 shows the feed rates for the test, and Table 2 gives the masses of SRS average salt feed compounds needed to prepare the $140 \mathrm{~L}$ of salt feed for the test. Table 3 gives the masses of the chemical compounds needed to prepare $37 \mathrm{~L}$ of synthetic recycle wash water. This was added to CSTR 1 along with the other feeds to simulate the recycle of wash water from the TPB recovery and recycle process. The quantity of synthetic wash water prepared assumed a 90 -h run time at $6.86 \mathrm{~mL} / \mathrm{min}$. The synthetic recycle water contained enough sodium tetraphenylborate (NaTPB), $0.03303 M$, to provide $60 \%$ excess of the stoichiometric NaTPB requirement to CSTR 1. To provide a stoichiometric amount of NaTPB to CSTR 1 to precipitate the potassium, $6.52 \mathrm{~L}$ of the NaTPB feed was needed $(0.68 \mathrm{~mL} / \mathrm{min}$ feed rate). The concentrations of NaTPB and $\mathrm{NaOH}$ in this feed solution were 0.5545 and $0.96 M$, respectively. A total of $1237.2 \mathrm{~g}$ NaTPB $[(0.5545 \mathrm{~mol} / \mathrm{L}) 3(6.52 \mathrm{~L}) 3(342.23 \mathrm{~g} / \mathrm{mol})]$ and $25.05 \mathrm{~g} \mathrm{NaOH} \quad[(0.096 \mathrm{~mol} / \mathrm{L})$ $3(6.52 \mathrm{~L}) 3(40 \mathrm{~g} / \mathrm{mol})]$ were needed for the preparation. The concentration of MST (preparation is given in reference 3) in the slurry solution in CSTR 1 was set at about $0.5 \mathrm{~g} / \mathrm{L}$. The concentration of ${ }^{137} \mathrm{Cs}$ in the salt feed (average SRS recipe) was $\sim 7.2 \mathrm{mCi} / \mathrm{L}$, which was diluted by other feeds to $\sim 5.5 \mathrm{mCi} / \mathrm{L}$ of slurry in the CSTRs. The concentration of ${ }^{85} \mathrm{Sr}$ and uranium $\left(93 \mathrm{wt} \%{ }^{235} \mathrm{U}\right)$ in the salt in the salt feed was $0.026 \mathrm{mCi} / \mathrm{L}$ and $0.8 \mathrm{ppm}$, respectively.

The CSTRs were filled prior to testing with salt feed and deionized water at a rate of 21.5 $\mathrm{mL} / \mathrm{min}$ salt feed and $7.78 \mathrm{~mL} / \mathrm{min}$ deionized water, providing a $\mathrm{Na}^{+}$concentration of $4.7 \mathrm{M}$. About $3 \mathrm{~L}$ of the diluted salt feed was added to the SCT after the CSTRs were filled. IITB52 antifoam was also added at a rate to provide concentrations of $50 \mathrm{ppm}$ in the CSTRs and $100 \mathrm{ppm}$ in the SCT. During the start-up phase, the CSTRs each received $0.77 \mathrm{~mL}$ of antifoam, and the SCT received $0.15 \mathrm{~mL}$ of antifoam. In addition, each $30-\mathrm{ft}$ antifoam line has a $2.7 \mathrm{~mL}$ capacity, so $2.7 \mathrm{~mL}$ was pre-fed through each line before starting to add the required volumes to the tanks. 
Table 1. Feed rates for CSTR feeds during Test 3

\begin{tabular}{|c|c|c|c|}
\hline \multirow{3}{*}{ Feed materials } & \multicolumn{3}{|c|}{ Feed rates } \\
\hline & \multicolumn{2}{|c|}{ Planned } & Actual \\
\hline & $(\mathrm{mL} / \mathrm{min})$ & $(\mathrm{mL} / \mathrm{h})$ & (mL/min) \\
\hline Salt feed & 21.5 & 1209 & 21.50 \\
\hline Recycle wash water with excess NaTPB & 6.86 & 411.6 & 7.35 \\
\hline MST + water & 2.14 & 128.4 & 2.08 \\
\hline NaTPB & 0.68 & 40.8 & 0.71 \\
\hline IITB52 feed to CSTR 1 and CSTR 2 & 0.00156 & 0.0935 & 0.00156 \\
\hline IITB52 feed to SCT & 0.00312 & 0.1871 & 0.00312 \\
\hline Total feed rate & 31.19 & & 31.64 \\
\hline
\end{tabular}

Table 2. Average SRS salt feed preparation for Test 3

\begin{tabular}{|c|c|c|c|c|c|}
\hline $\begin{array}{l}\text { Chemical } \\
\text { Specie }\end{array}$ & $\begin{array}{l}\text { Molarity } \\
(\mathrm{mol} / \mathrm{L})\end{array}$ & Compound & $\begin{array}{c}\text { Molecular weight } \\
(\mathrm{g} / \mathrm{mol})\end{array}$ & $\begin{array}{l}\text { Mass } \\
(\mathrm{g} / \mathrm{L})\end{array}$ & $\begin{array}{c}{\text { Test } 3 \text { mass }^{a, b}}_{(\mathrm{g} / 151.4 \mathrm{~L})}\end{array}$ \\
\hline $\mathrm{Cs}^{-c}$ & 0.00016 & $\mathrm{CsCl}$ & 168.36 & 0.027 & 4.1 \\
\hline $\mathrm{K}^{-}$ & 0.0171 & $\mathrm{KNO}_{3}$ & 101.1 & 1.729 & 261.8 \\
\hline $\mathrm{OH}^{-}$ & 3.611 & $\mathrm{NaOH}$ & 40.00 & 144.44 & $21,868.2$ \\
\hline $\mathrm{NO}_{3}^{-}$ & $1.365^{d}$ & $\mathrm{NaNO}_{3}$ & 84.99 & 116.01 & $17,563.9$ \\
\hline $\mathrm{NO}_{2}^{-}$ & 0.594 & $\mathrm{NaNO}_{2}$ & 69.00 & 40.99 & $6,205.9$ \\
\hline $\mathrm{AlO}_{2}^{-}$ & 0.354 & $\mathrm{Al}\left(\mathrm{NO}_{3}\right)_{3} \quad 9 \mathrm{H}_{2} \mathrm{O}$ & 375.14 & 132.80 & $20,105.9$ \\
\hline $\mathrm{CO}_{3}{ }^{2-}$ & 0.183 & $\mathrm{Na}_{2} \mathrm{CO}_{3} \mathrm{H}_{2} \mathrm{O}$ & 124.01 & 22.69 & $3,435.3$ \\
\hline $\mathrm{SO}_{4}{ }^{2-}$ & 0.171 & $\mathrm{Na}_{2} \mathrm{SO}_{4}$ & 142.04 & 24.29 & $3,677.5$ \\
\hline $\mathrm{Cl}^{-}$ & 0.0286 & $\mathrm{NaCl}$ & 58.4 & 1.670 & 252.9 \\
\hline $\mathrm{F}^{-}$ & 0.0366 & $\mathrm{NaF}$ & 41.99 & 1.537 & 232.7 \\
\hline $\mathrm{HPO}_{4}{ }^{2-}$ & 0.0114 & $\mathrm{Na}_{2} \mathrm{HPO}_{4} 7 \mathrm{H}_{2} \mathrm{O}$ & 268.09 & 3.056 & 462.7 \\
\hline $\mathrm{C}_{2} \mathrm{O}_{4}{ }^{2-}$ & 0.0091 & $\mathrm{Na}_{2} \mathrm{C}_{2} \mathrm{O}_{4}$ & 134.00 & 1.219 & 184.6 \\
\hline $\mathrm{SiO}_{3}{ }^{2-}$ & 0.0046 & $\mathrm{Na}_{2} \mathrm{SiO}_{3} 9 \mathrm{H}_{2} \mathrm{O}$ & 284.2 & 1.307 & 197.9 \\
\hline $\mathrm{MoO}_{4}{ }^{2-}$ & 0.00023 & $\mathrm{Na}_{2} \mathrm{MoO}_{4} \quad 2 \mathrm{H}_{2} \mathrm{O}$ & 241.95 & 0.056 & 8.5 \\
\hline $\mathrm{Sr}^{2+e}$ & & $\mathrm{Sr}\left(\mathrm{NO}_{3}\right)_{2}$ & 211.75 & 0.000011 & 0.0167 \\
\hline Uranium $^{e}$ & & $\mathrm{UO}_{2}\left(\mathrm{NO}_{3}\right)_{2}$ & 391.13 & 0.00154 & 0.2332 \\
\hline $\mathrm{Na}^{+}$ & 6.394 & & & & \\
\hline $\mathrm{H}_{2} \mathrm{O}$ & & & & 796. & 120,514 \\
\hline & & Totals & & $1,289.8$ & 195,276 \\
\hline
\end{tabular}

${ }^{a}$ Assumes 90 -h run time at $21.5 \mathrm{~mL}$ (salt feed)/min, or $0.412 \mathrm{~L}$ (salt feed) $/ \mathrm{h}$; also accounts for salt feed added to CSTRs and SCT at beginning of test.

${ }^{b}$ Calculated density $=(195,276 \mathrm{~g}) /(151,400 \mathrm{~mL})=1.29 \mathrm{~g} / \mathrm{mL}(140 \mathrm{~L}$ of salt feed was actually added to feed tanks in Hot Cell C and the tracers were added with good mixing; measured density was $1.281 \mathrm{~g} / \mathrm{mL}$ ).

${ }^{c} 4.21 \mathrm{~g}$ of $\mathrm{Cs} \mathrm{Cl}\left(3.32 \mathrm{~g} \mathrm{Cs}\right.$ ) in $70 \mathrm{~mL}$ water was mixed well with $1.35 \mathrm{Ci}^{137}$ tracer (mass of $\mathrm{Ci}^{137}$ was 0.016 ; but total cesium mass in tracer was $0.073 \mathrm{~g}$ ). The total mass of ${ }^{133} \mathrm{Cs}$ and ${ }^{137} \mathrm{Cs}$ used in Test 3 was $3.393 \mathrm{~g}$, which provided the needed $0.000167 \mathrm{M}$ cesium in the salt feed. The ${ }^{137} \mathrm{Cs}$ concentration in the salt feed was $9.1 \mathrm{mCi} / \mathrm{L}$ and $6.3 \mathrm{mCi} / \mathrm{L}$ in the $4.7 \mathrm{M} \mathrm{Na}^{+}$slurry.

${ }^{d}$ The target molarity for $\mathrm{NO}_{3}{ }^{-}$is $2.45 \mathrm{~mol} / \mathrm{L}$. The addition of $\mathrm{Al}\left(\mathrm{NO}_{3}\right)_{3} 9 \mathrm{H}_{2} \mathrm{O}$ and $\mathrm{KNO}_{3}$ provides 1.062 and $0.017 \mathrm{~mol} \mathrm{NO}_{3} / \mathrm{L}$, respectively. [2.45 $\left.-(1.068+0.017)\right]=1.365 \mathrm{~mol}\left(\mathrm{NaNO}_{3}\right) / \mathrm{L}$ extra needed].

${ }^{e}$ Strontium- 85 was added to obtain a feed concentration of $(0.068 \mathrm{mCi} / \mathrm{L})$ and cold strontium was added to obtain a concentration of $0.047 \mathrm{mg} / \mathrm{L}$, and uranium $\left(93 \%{ }^{235} \mathrm{U}\right)$ was added to obtain a concentration of $0.93 \mathrm{mg} / \mathrm{L}$. The calculated strontium and uranium concentration for the $4.7 \mathrm{M} \mathrm{Na}^{+}$slurry were $0.032 \mathrm{mg} / \mathrm{L}(0.046 \mathrm{mCi} / \mathrm{L})$ and $0.64 \mathrm{mg} / \mathrm{L}$, respectively. Details about the preparations of the strontium and uranium stock solutions used can be found in ref. 3 . 
Table 3. Simulated recycle solution preparation for Test 3

\begin{tabular}{|c|c|c|c|c|c|}
\hline $\begin{array}{l}\text { Chemical } \\
\text { specie }\end{array}$ & $\begin{array}{l}\text { Molarity } \\
(\mathrm{mol} / \mathrm{L})\end{array}$ & Compound & $\begin{array}{l}\text { Molecular } \\
\text { weight } \\
(\mathrm{g} / \mathrm{mol})\end{array}$ & $\begin{array}{c}\text { Mass } \\
\text { Fraction } \\
(\mathrm{g} / \mathrm{L})\end{array}$ & $\begin{array}{l}\text { Total } \\
\text { mass }^{a, b} \\
(\mathrm{~g} / 37 \mathrm{~L})\end{array}$ \\
\hline $\mathrm{TPB}^{-}$ & 0.03303 & NaTPB & 342.23 & 11.30 & 418.10 \\
\hline $\mathrm{OH}^{-}$ & 0.6584 & $\mathrm{NaOH}$ & 40.00 & 26.346 & 974.80 \\
\hline $\mathrm{NO}_{3}^{-}$ & 0.2531 & $\mathrm{NaNO}_{3}$ & 84.99 & 21.248 & 786.18 \\
\hline $\mathrm{NO}_{2}^{-}$ & 0.1083 & $\mathrm{NaNO}_{2}$ & 69.00 & 7.473 & 276.50 \\
\hline $\mathrm{AlO}_{2}^{-}$ & 0.0645 & $\mathrm{Al}\left(\mathrm{NO}_{3}\right)_{3}, 9 \mathrm{H}_{2} \mathrm{O}$ & 375.14 & 24.196 & 895.25 \\
\hline $\mathrm{CO}_{3}{ }^{2-}$ & 0.0334 & $\mathrm{Na}_{2} \mathrm{CO}_{3} \mathrm{H}_{2} \mathrm{O}$ & 124.01 & 4.142 & 153.25 \\
\hline $\mathrm{SO}_{4}^{2-}$ & 0.0312 & $\mathrm{Na}_{2} \mathrm{SO}_{4}$ & 142.04 & 4.432 & 163.98 \\
\hline $\mathrm{Cl}^{-}$ & 0.0052 & $\mathrm{NaCl}$ & 58.4 & 0.304 & 11.25 \\
\hline $\mathrm{F}$ & 0.0067 & $\mathrm{NaF}$ & 41.99 & 0.281 & 10.40 \\
\hline $\mathrm{HPO}_{4}{ }^{2-}$ & 0.0015 & $\mathrm{Na}_{2} \mathrm{HPO}_{4} 7 \mathrm{H}_{2} \mathrm{O}$ & 268.09 & 0.563 & 25.33 \\
\hline $\mathrm{C}_{2} \mathrm{O}_{4}{ }^{2-}$ & 0.0017 & $\mathrm{Na}_{2} \mathrm{C}_{2} \mathrm{O}_{4}$ & 134.00 & 0.228 & 8.44 \\
\hline $\mathrm{SiO}_{3}{ }^{2-}$ & 0.0008 & $\mathrm{Na}_{2} \mathrm{SiO}_{3} \quad 9 \mathrm{H}_{2} \mathrm{O}$ & 284.2 & 0.227 & 8.40 \\
\hline $\mathrm{MoO}_{4}{ }^{2-}$ & 0.00004 & $\mathrm{Na}_{2} \mathrm{MoO}_{4} 2 \mathrm{H}_{2} \mathrm{O}$ & 241.95 & 0.0097 & 0.36 \\
\hline $\mathrm{Na}^{+}$ & 1.20 & & & & \\
\hline \multirow[t]{2}{*}{$\mathrm{H}_{2} \mathrm{O}$} & & & & 950 & 35,150 \\
\hline & & & Totals & $1,050.75$ & $38,882.2$ \\
\hline
\end{tabular}

\section{MEASUREMENTS AND SAMPLING}

\subsection{SAMPLING PLANS AND METHODS}

During the tests, samples were taken for analysis according to the sampling plan given in CERS/SR/TPB/006, Rev. 1, Sampling Plan and Procedures. ${ }^{4}$ After preparation, the salt feed solution was analyzed for $\mathrm{K},{ }^{137} \mathrm{Cs}$, and ${ }^{85} \mathrm{Sr}$. Effluent samples were taken for each CSTR (sample ports 1 and 2), and a filtrate sample was taken from the SCT filtration system (sample port 4) every $4 \mathrm{~h}$ (samples of 55$65 \mathrm{~mL}$ each, collected over a 2 min duration). Each sample was analyzed using an on-site gamma counter for ${ }^{137} \mathrm{Cs}$ and ${ }^{85} \mathrm{Sr}$. The counter results indicated an error margin of $\pm 10 \%$ and minimum detectable levels of $3 \mathrm{E}-5 \mu \mathrm{Ci} / \mathrm{g}$ for both ${ }^{85} \mathrm{Sr}$ and ${ }^{137} \mathrm{Cs}$. At 8 -h time intervals, duplicate samples were analyzed by the ORNL Radioactive Materials Analysis Laboratory (RMAL) for ${ }^{137} \mathrm{Cs}( \pm 10 \%$ error margin), ${ }^{85} \mathrm{Sr}( \pm 10 \%),{ }^{235} \mathrm{U}( \pm 10 \%), \mathrm{K}( \pm 10 \%), \mathrm{B}( \pm 10 \%)$, and NaTPB $( \pm 20 \%)$. Every fifth sample (20-h interval) was analyzed by Reverse-Phase High-Performance Liquid Chromatography (HPLC) for TPB decomposition products. Portions of some of the samples were analyzed for uranium by delayed neutron counting ( $\pm 10 \%$ error margin). The slurry samples from the CSTRs were also examined for the presence of foam. Other samples were archived in case additional data were needed.

Samples from sample ports 1 (SP-1) and 2 (SP-2) were prepared for analysis by filtering the sample through either a $0.45-\mu \mathrm{m}$ filter or a $0.80 / 0.22-\mu \mathrm{m}$ double filter and placing the filtrate in new sample bottles for transfer to RMAL. Some of the samples were very difficult to filter with the $0.45-\mu \mathrm{m}$ filter, which necessitated use of the double filter. The double-filter design facilitated easier and faster filtration of the sample, which reduced personnel radiation dose and the potential for contamination issues. Analytical results for the same sample, filtered using both methods, were comparable. HPLC was used for NaTPB and TPB decomposition products, including triphenylborane (3PB), diphenylborinic 
acid (2PB), phenylboronic acid, and phenol. Official gamma counting by RMAL was performed using either Canberra or ORTEC GMX closed-end coaxial detectors for ${ }^{137} \mathrm{Cs}$ and strontium $\left({ }^{85} \mathrm{Sr}\right)$ with an error margin of $\pm 10 \%$. Inductively coupled plasma Atomic Emission Spectroscopy (ICP-AES) was used for potassium and boron analysis. Prior to analysis, potassium and boron samples were digested in nitric acid in a microwave oven. The filtrate samples from SCT (sample port 4) were sent, as collected, to RMAL for analysis after a small sample $(1-3 \mathrm{~mL})$ was placed in a counting tube for on-site ${ }^{137} \mathrm{Cs}$ and ${ }^{85} \mathrm{Sr}$ counting. All samples destined for RMAL were placed in a refrigerator $\left(2-4^{\circ} \mathrm{C}\right)$ after preparation, until they could be transported. A chain-of-custody procedure in accordance with the Sample Management Office was followed for all samples sent to RMAL.

\subsection{MEASURING AND TEST EQUIPMENT}

Electronic balances, which are calibrated annually by ORNL Plant and Equipment (P\&E) personnel, were used for solids and liquid mass measurements in preparing the simulants. Class A volumetric flasks and graduated cylinders were used for simulant preparation. For on-site monitoring of

${ }^{137} \mathrm{Cs}$ and ${ }^{85} \mathrm{Sr}$ during the CSTR tests, a gamma-counting system consisting of an ORTEC model GMX45220-P-S intrinsic germanium detector, an ORTEC model 672 counting system amplifier, a Canberra Accuspec-A MCA card, and Canberra Genie-2000 spectroscopy software was used.

Instrumentation used in the CSTR system was calibrated before startup. Calibration records are maintained in registered logbooks and in a controlled project file. A revised list of instruments and corresponding calibration schedules was generated after the modifications to the CSTR system had been reviewed and approved by the SPP and Oak Ridge investigators.

\section{RESULTS OF TEST 3}

\subsection{RUN SUMMARY}

Test 3 was successfully conducted August 14-18, 2000, with no unscheduled downtime. During the operation, a total of about $93 \mathrm{~L}$ (24.5 gal) of radioactive simulated SRS salt feed was treated with $\sim 135 \mathrm{~L}(\sim 36 \mathrm{gal})$ of decontaminated filtrate and $\sim 6.5 \mathrm{~L}$ of concentrated TPB/MST slurry ( $>9$ wt $\%$ insoluble solids) collected. Overall, the DF values for cesium, strontium, and uranium exceeded the WAC standards needed for filtrate disposal in saltstone. The concentration of the NaTPB in the recycle water provided 60\% excess NaTPB to ensure the needed cesium DF of 40,000. Figure 9 shows the ${ }^{137}$ Cs- DFs versus time profiles for CSTR 1, CSTR 2, and the Slurry Concentration Vessel. A DF of 40,000 was obtained in CSTR 1 about $12 \mathrm{~h}$ after the initiation of NaTPB feed. This DF was also achieved in CSTR 2 after about $26 \mathrm{~h}$. In the Slurry Concentration Tank, the DF for cesium reached 10,000 in about $36 \mathrm{~h}$ and 40,000 in about $70 \mathrm{~h}$. Periods of 12, 18, and $22 \mathrm{~h}$, respectively, were required to obtain a DF of 2 for uranium in CSTR 1, CSTR 2, and the SCT. A DF of about 5 for uranium was obtained at the end of the test in the concentrate filtrate. As shown in Fig. 10, the loss of DF for uranium was very noticeable for CSTR 1 in the 64- to 72-h samples and for CSTR 2 in the 68- and 72-h samples as the concentration increased. During this period, the MST feed line to CSTR 1 became disconnected at a location not visible to operating personnel. After about $6 \mathrm{~h}$, the disconnected line was discovered and repaired. Figure 11 shows the DF versus time profile for ${ }^{85} \mathrm{Sr}$. After $36 \mathrm{~h}$, a strontium DF of 30 was obtained in the SCT, and the DF slowly increased to about 50 at the end of the test.

The overall system operation was performed in accordance with the test plans, and the behavior of the system components and overall system performance satisfied the test objectives. No foam was detected in any slurry samples from CSTR 1 or CSTR 2. No foam was visible in the slurry transfer lines between CSTR 1 and CSTR 2, between CSTR 2 and the SCT, and no other problems with slurry transfer occurred. The most difficult operational problems in Test 3 occurred with the MST/dilution water 


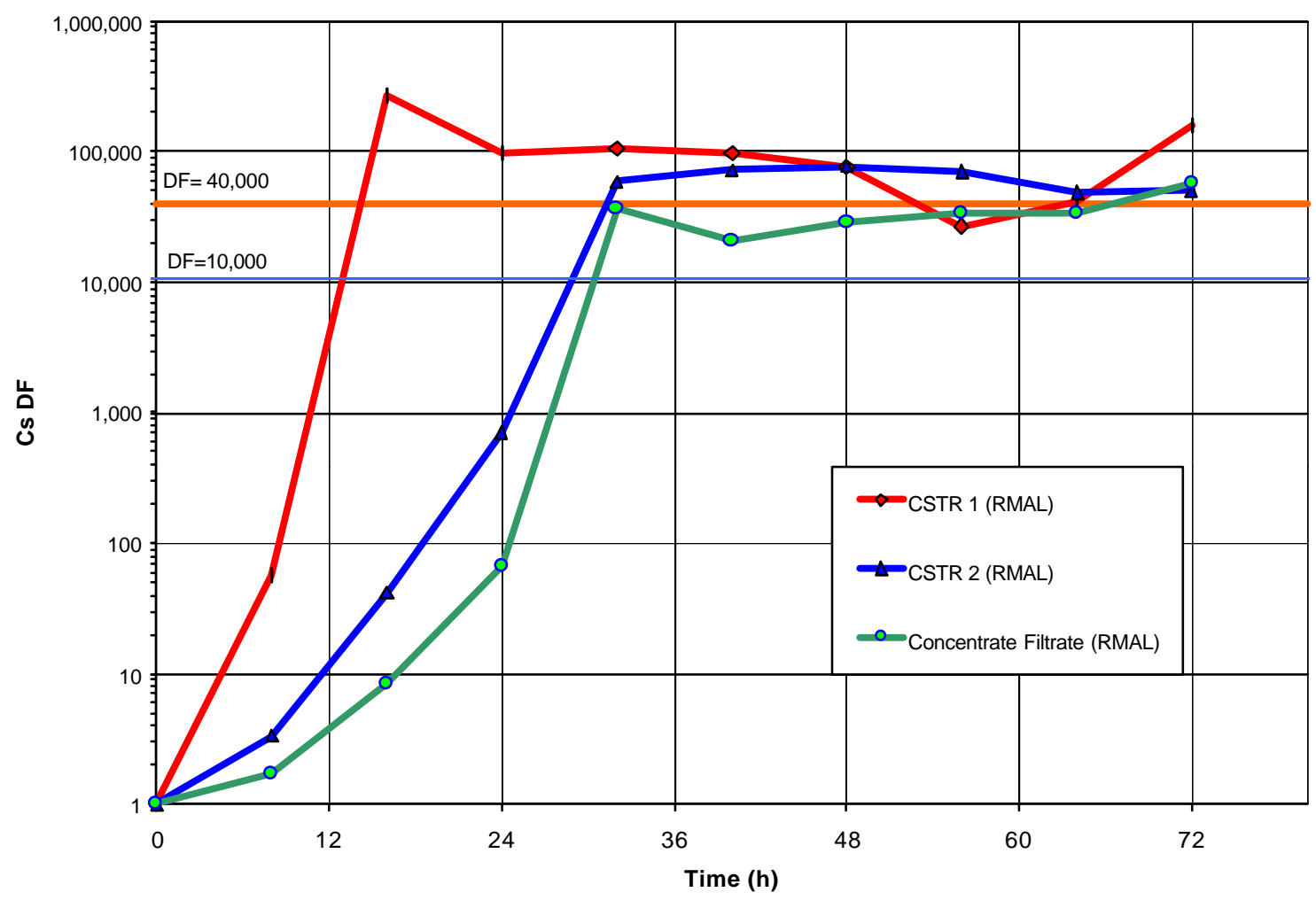

Fig. 9. Test $3^{137} \mathrm{Cs}$ DF.

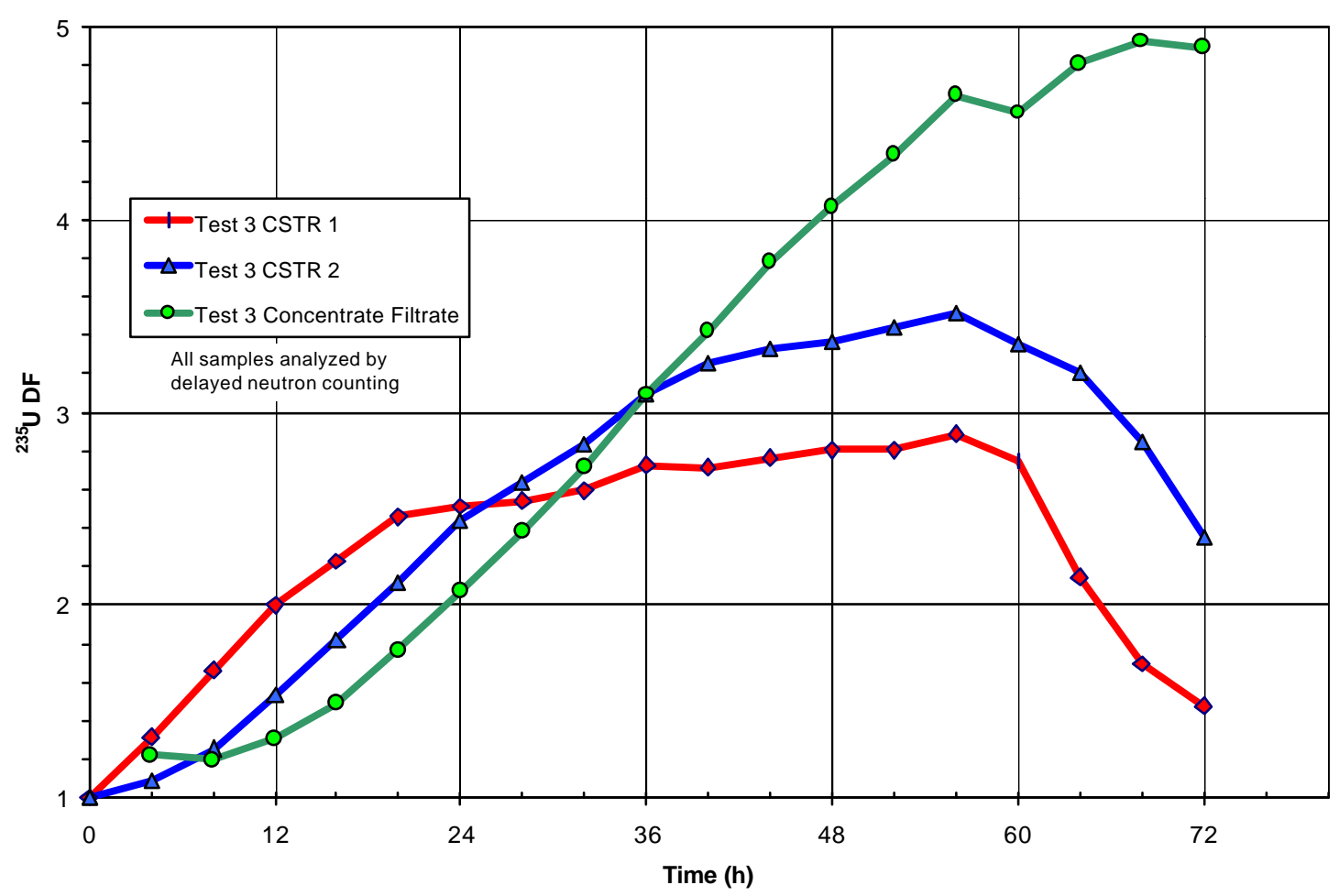

Fig. 10. Test $3{ }^{235} \mathrm{U}$ DF. 


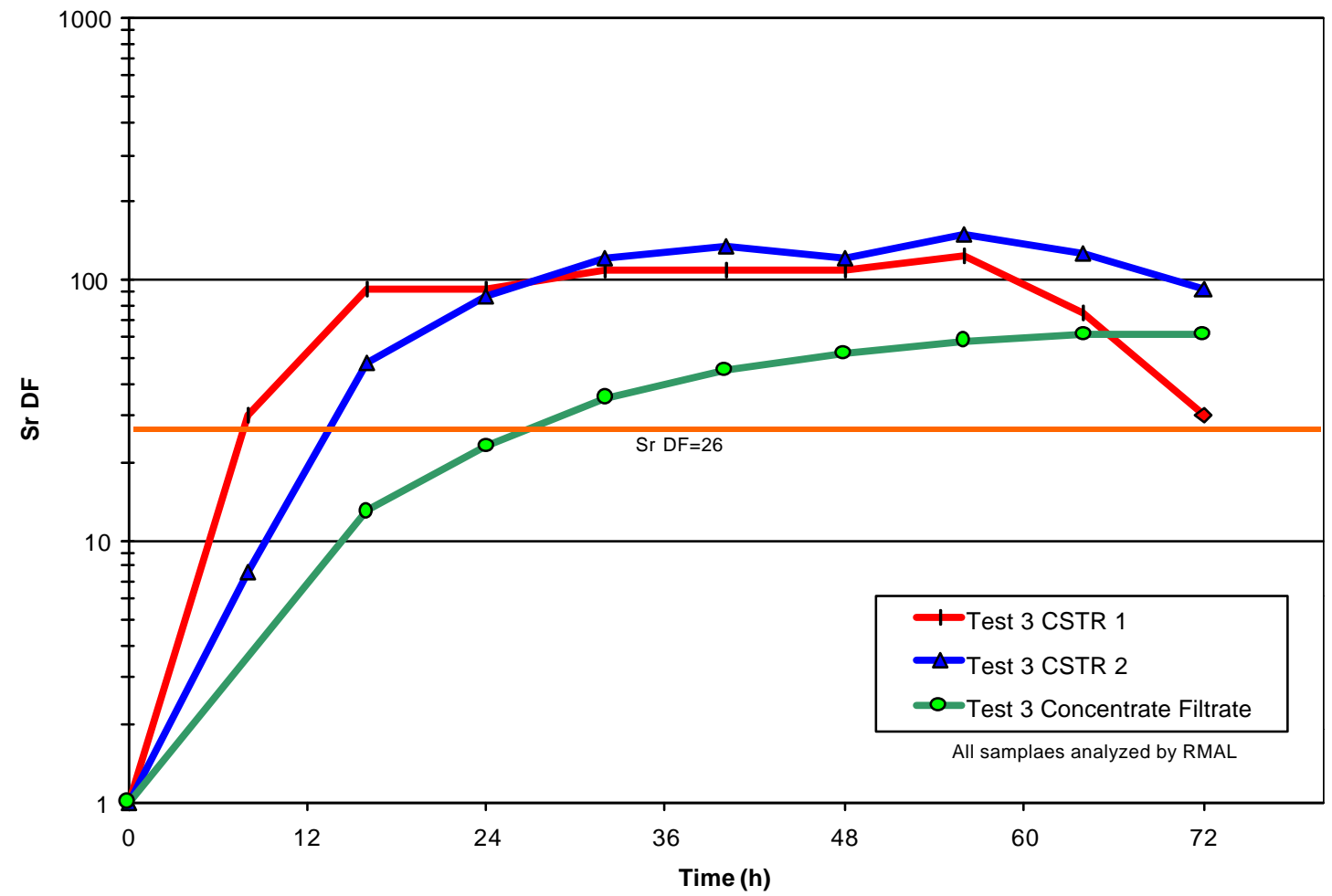

Fig. 11. Test $3{ }^{85} \mathrm{Sr} \mathrm{DF}$.

delivery system. The planned and actual flow summary is shown in Table 4. Afterward, both cross-flow filter systems were chemically cleaned with $2 \%$ oxalic acid solution, rinsed well with water, and then rinsed and stored in $1 M \mathrm{NaOH}$.

Table 4. Process performance for Test 3

\begin{tabular}{|c|c|c|c|}
\hline & $\begin{array}{l}\text { Planned volume } \\
\text { (L) }\end{array}$ & $\begin{array}{c}\text { Actual volume } \\
\text { (L) }\end{array}$ & $\begin{array}{l}\text { Average } \\
\text { flow rates } \\
(\mathrm{mL} / \mathrm{min})\end{array}$ \\
\hline Salt feed & 92.88 & 93.02 & 21.53 \\
\hline Recycle wash water & 29.64 & 29.78 & 6.89 \\
\hline NaTPB & 2.938 & 2.980 & 0.69 \\
\hline Water + MST & 8.94 & $8.84^{a}$ & 2.05 \\
\hline Antifoam to CSTR 1 & 0.00673 & 0.00673 & 0.00156 \\
\hline Antifoam to CSTR 2 & 0.00673 & 0.00673 & 0.00156 \\
\hline Antifoam to SCT & 0.01346 & 0.01346 & 0.00312 \\
\hline $\begin{array}{l}\text { Filtrate from cross-flow } \\
\text { filter }\end{array}$ & 127.1 & $\begin{array}{l}124.7 \text { (plus } \sim 2 \text {-L holdup in } \\
\text { pipes and wash system } \\
\text { vessels }\end{array}$ & 29.02 \\
\hline Slurry produced & 6.5 & 6.5 & \\
\hline
\end{tabular}

${ }^{a}$ Flow was interrupted during the last 6 to $8 \mathrm{~h}$ of MST/water feed due to an undetected breach in the feed tubing. 


\subsection{DETAILS OF SYSTEM CHEMISTRY}

\subsubsection{Cesium Decontamination of Test 3 Salt Feed}

Figure 9 shows the DFs for cesium obtained during Test 3 in the CSTRs and the SCT filtrates based upon RMAL counting results. $\mathrm{A} \mathrm{DF}_{\mathrm{Cs}}$ of 40,000 was obtained in $14 \mathrm{~h}$ for CSTR 1 and thereafter ranged between 41,000 and 270,000. Only one sample at $56 \mathrm{~h}$ had a $\mathrm{DF}_{\mathrm{Cs}}$ less than 40,000; it was 27,000. It took about $32 \mathrm{~h}$ to reach 40,000 in CSTR 2. Afterward, the $\mathrm{DF}_{\mathrm{Cs}}$ ranged from 49,000 to 77,000 . A $\mathrm{DF}_{\mathrm{Cs}}$ of 37,000 was obtained in the SCT in about $32 \mathrm{~h}$. It subsequently fluctuated between 21,000 and 59,000 and reached the highest value at the end of the test. Cesium concentrations obtained by both onsite and RMAL counting for all the system vessels agreed very well, as shown in Fig. 12. These data show a decrease in concentration of ${ }^{137} \mathrm{Cs}$ as a function of test time in each of the vessel until the minimum cesium concentration is reached. In CSTRs 1 and 2, the concentration then slightly increases as steady state is approached. The RMAL data consistently showed slightly lower cesium concentrations for each filtrate sample. The long delay in obtaining $\mathrm{DF}_{\mathrm{Cs}}$, especially in the SCT filtrate, was the result of the method of starting the test (i.e., the vessels were filled with radioactively traced salt feed simulant before TPB was supplied). As TPB was added, the cesium and potassium reacted with TPB and precip itated. The soluble concentrations of these elements decreased until a state of equilibrium was established. To ensure a high DF, a mole ratio of TPB to potassium and cesium of 1.6 to 1 was used. Part of the delay in obtaining a high cesium DF in SCT filtrate was caused by the untreated salt feed retention in the 700-mL pressure vessel that was used for backpulsing the cross-flow filter. The cesium and potassium in the untreated salt feed in this vessel were slowly replaced by the treated filtrate.

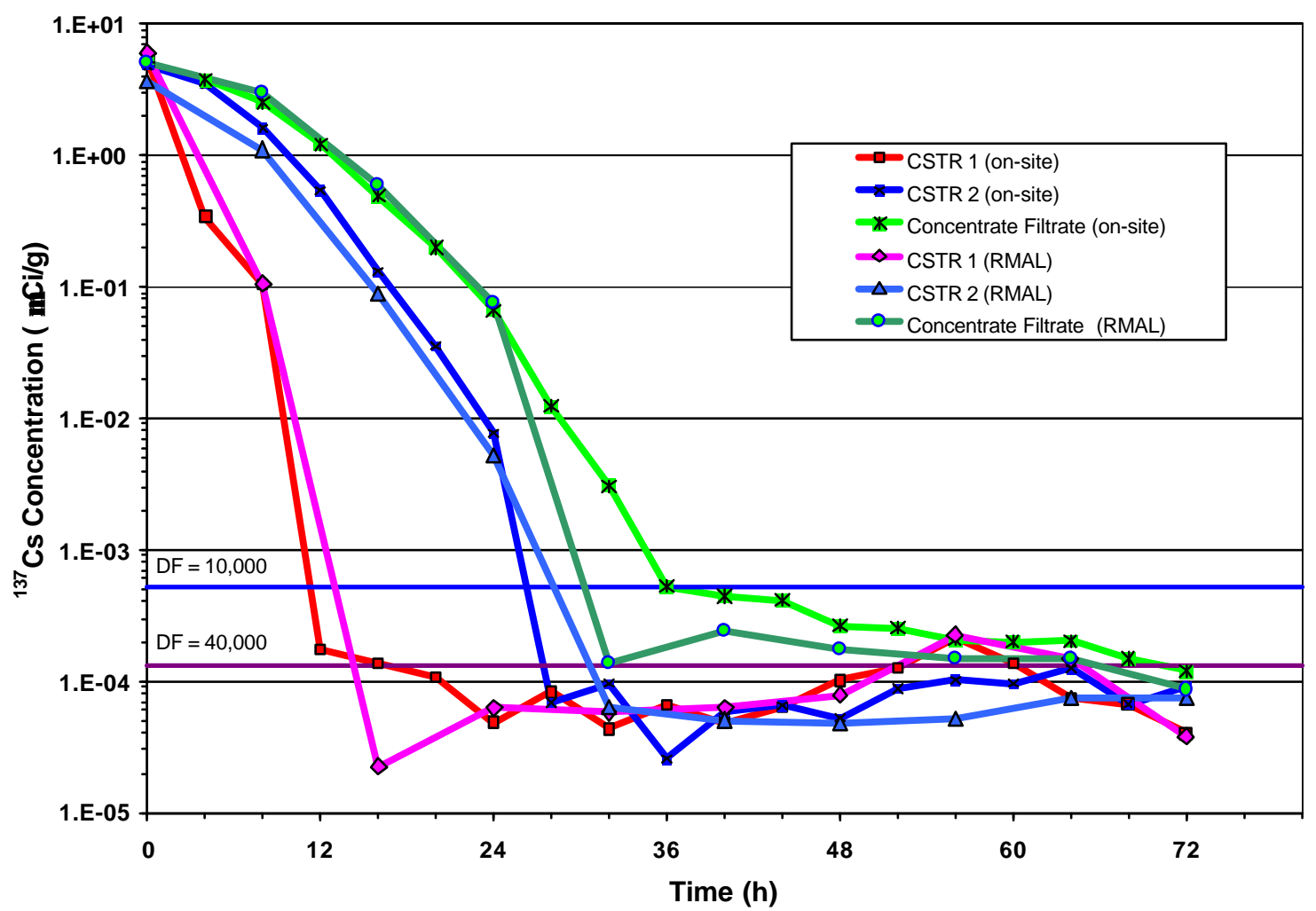

Fig. 12. ${ }^{137}$ Cs after CSTR 1, CSTR 2, and in the concentrate filtrate during Test 3. 
Cesium removal data from Tests 1a and 2 was compared to the results of Test 3 to evaluate differences in cesium removal performance. Figures 13-15 show the cesium removal data, as determined by on-site gamma counting (only the first 72 hours of Test 2 are shown). All three tests were begun in the same way, with Tests 1a and 3 identical except for the higher agitator speeds and the antifoam addition in Test 3. Test 2 had he modified Enhanced Comprehensive Catalyst system added to the feed that contained a number of hydrous metal oxides that may have affected the rate of TPB precipitation of the potassium and cesium; otherwise, it was the same as Test 1a during startup. The results for the two CSTRs for Test $1 \mathrm{a}$ and Test 3 were similar in that a $\mathrm{DF}_{\mathrm{Cs}}$ of $>40,000$ was obtained at about the same operating time. Overall, judging by the data, the IITB52 antifoam used in Test 3 apparently had no impact on the cesium precipitation process.

\subsubsection{Strontium Decontamination of Test 3 Salt Feed}

Figure 11, which shows RMAL (official) gamma counting data, indicates the DFs obtained for ${ }^{85} \mathrm{Sr}$ removal by MST powder from the diluted salt feed in the CSTRs and SCT. Figure 16 shows the concentrations of both RMAL and on-site data for the CSTRs and SCT and the agreement is generally good. According to the RMAL counting data, it required about $24 \mathrm{~h}$ to obtain a DF of 30 for strontium in the SCT; the $\mathrm{DF}_{\mathrm{Sr}}$ slowly increased to about 100 at the end of the test. A DF 26 was needed to reach the WAC standard for saltstone. The reasons for the delay in obtaining the desired $\mathrm{DF}_{\mathrm{Sr}}$ were similar to those that delayed reaching the desired $\mathrm{DF}_{\mathrm{Cs}}$. At the start of the test, the strontium-to-MST ratio was very high and the rate of sorption is somewhat slow. Moreover, the delay at the start is increased by the untreated salt feed in the $700 \mathrm{~mL}$ back-pulsing pressure vessel. The IITB52 did not appear to impede the sorption of strontium by the MST. These data show that a decrease was noted in the DF Sr $_{\text {for CSTR } 1}$ during the last $+8 \mathrm{~h}$ of the test that occurred when the MST feed line to CSTR 1 came loose at a valve fitting. It was not detected until the filtrate samples taken during this time period were counted, alerting the operators to the problem. The balance data for the MST/water feed tank showed no loss of flow. The $\mathrm{DF}_{\mathrm{Sr}}$ for CSTR 2 was also beginning to decrease at the end of the test.

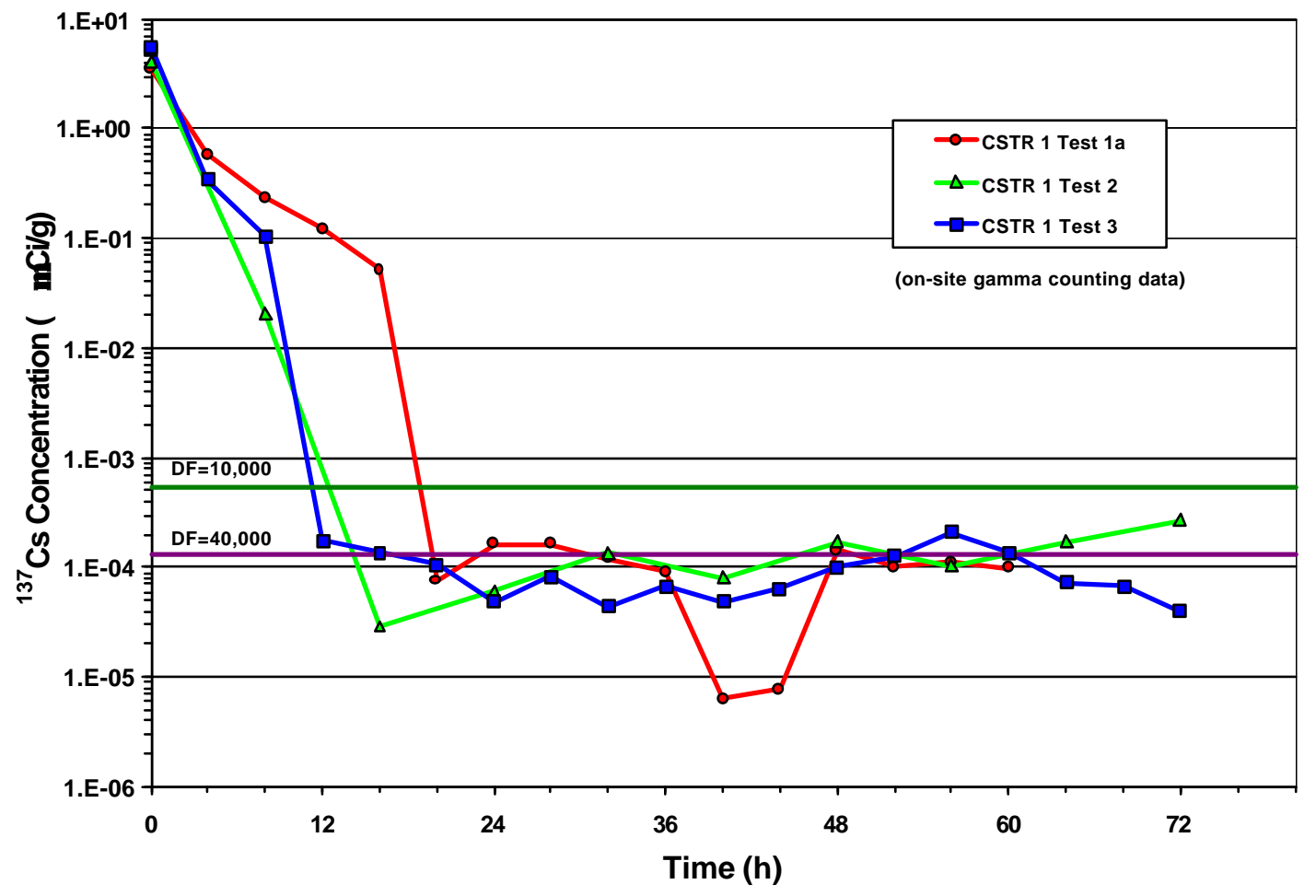

Fig. 13. Comparison of ${ }^{137}$ Cs removal for Tests 1,2 , and 3 for CSTR 1. 


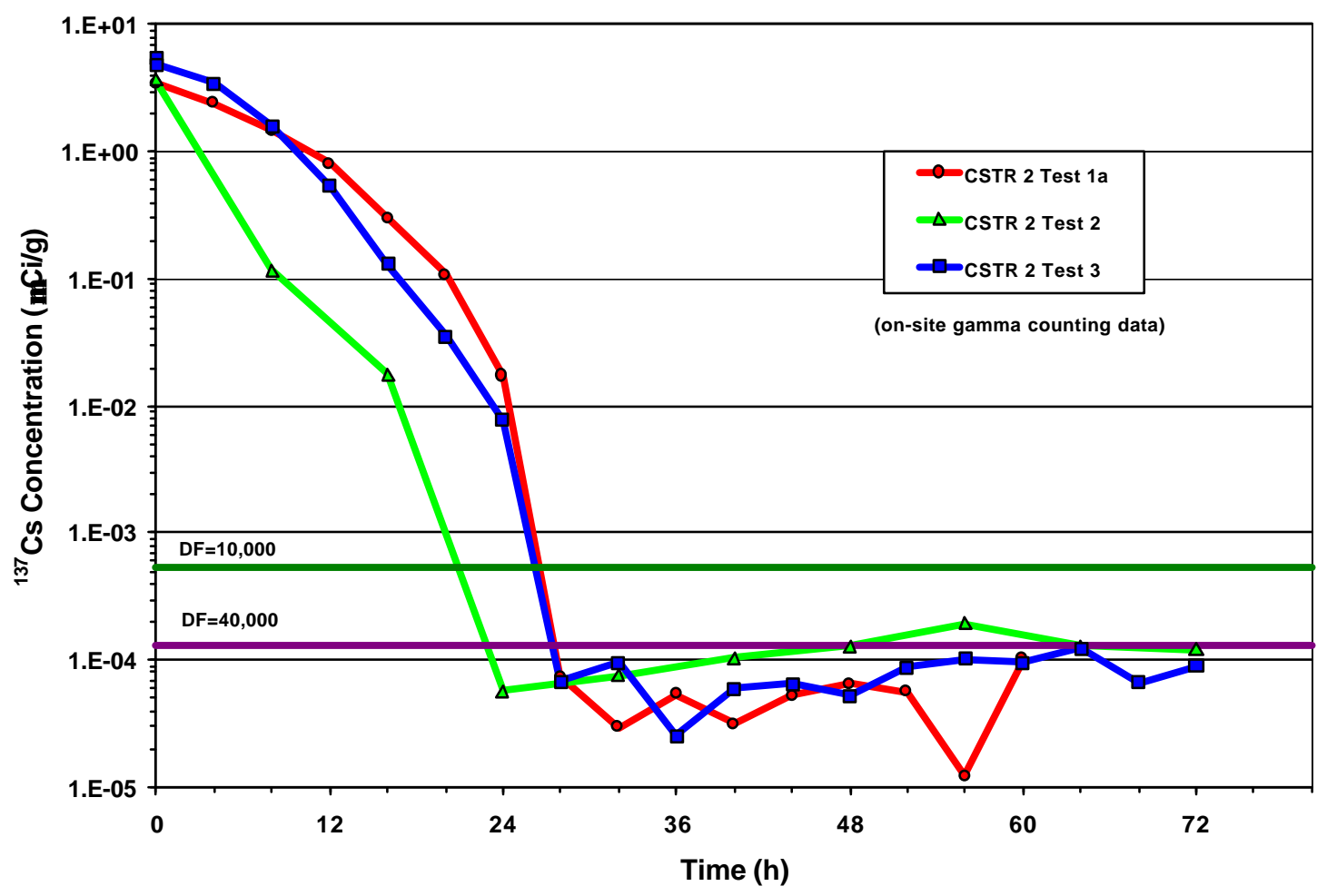

Fig. 14. Comparison of ${ }^{137}$ Cs removal for Tests 1, 2, and 3 for CSTR 2.

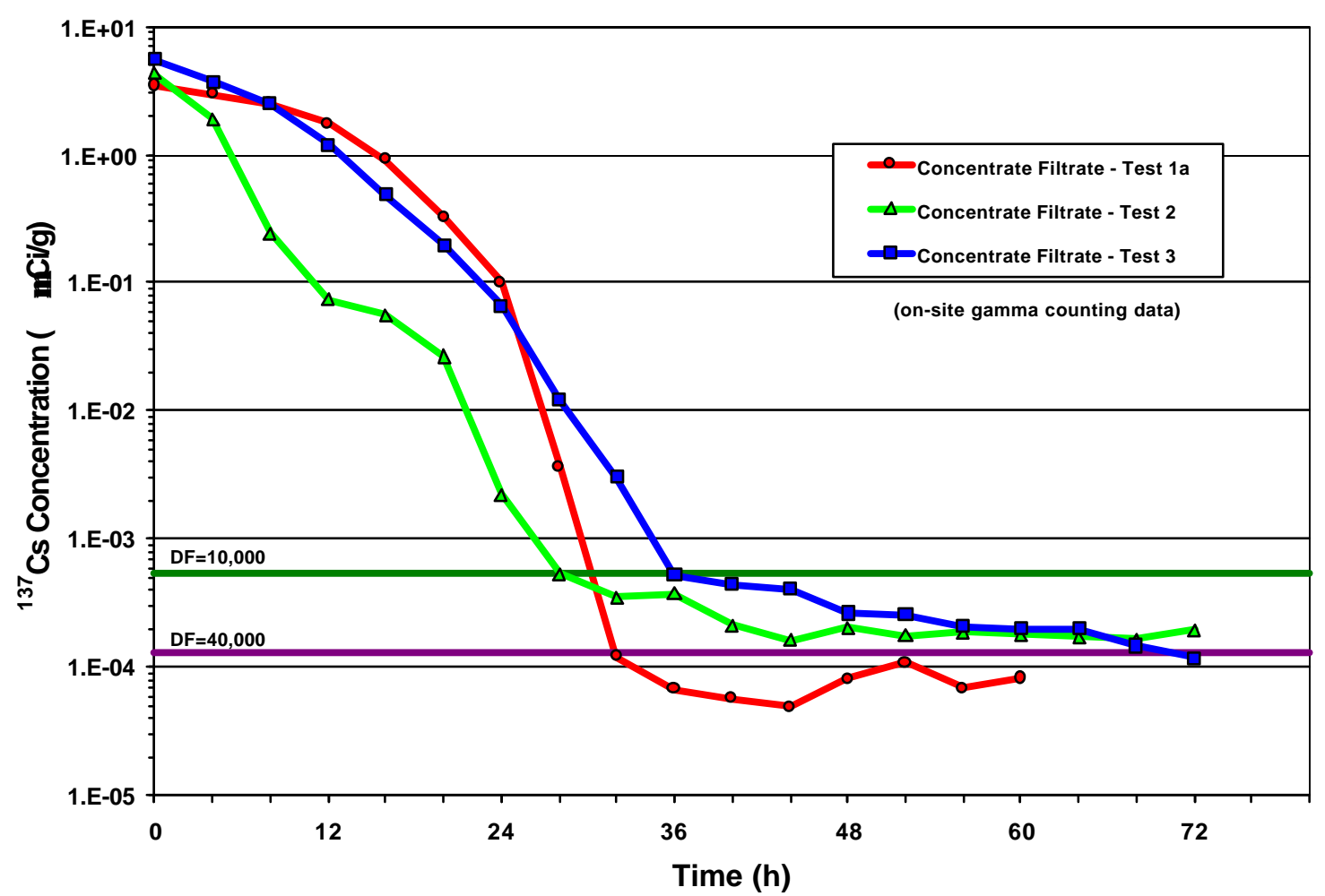

Fig. 15. Comparison of ${ }^{137} \mathrm{Cs}$ removal for Tests 1,2 , and 3 for concentrate filtrate. 


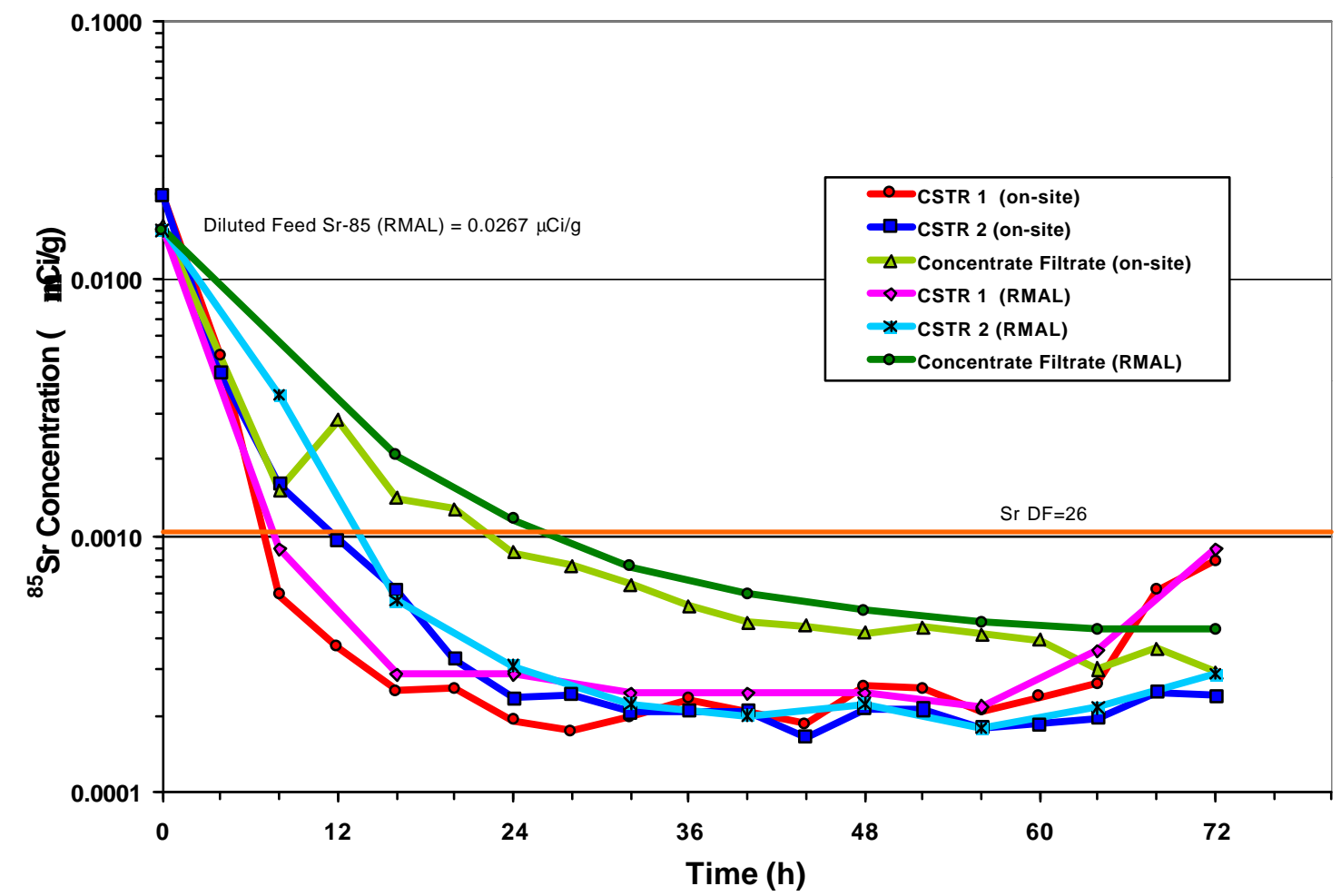

Fig. 16. Strontium concentrations during Test 3.

The RMAL strontium removal results for Test 1a and 3 for all the vessels are compared in Fig. 17, and the on-site results for individual vessels are provided in Figs. 18-20. There is fairly good agreement in the shape of the curves, but the percentage removal in Test 3 was greater. It is speculated that the increased mixer speed used in Test 3 contributed to the improved strontium removal. A decrease in $\mathrm{DF}_{\mathrm{Sr}}$ for Test 3, as indicated by an increase in the strontium concentration, occurred during the last three or four sample periods in both CSTRs due to the inadvertent loss in MST feed. The stage effect of the three vessels is apparent for both strontium and uranium, as the concentration of both are progressively lower for CSTR 1, CSTR 2, and the SCT. The data indicates no interference of the IITB52 antifoam with strontium removal for this test.

\subsubsection{Uranium Decontamination of Test 3 Salt Feed}

As measured by RMAL, a DF of 5 for uranium in the SCT was obtained at the end of the test, as shown in Fig. 10. This indicates that the other actinides (neptunium and plutonium), had they been present in the salt feed, probably would have been removed to meet WAC standards. A $\mathrm{DF}_{\mathrm{U}}$ of 2 was reached after 12, 18, and $22 \mathrm{~h}$ in CSTR 1, CSTR 2, and the SCT, respectively. Later in the test, as steady-state conditions were approached, the concentrations of uranium in the three process vessels were aligned in accordance with the expected stagewise behavior of the process: the concentration in CSTR 1 was greater than CSTR 2, and the lowest uranium concentration was in the SCT. The data demonstrate the importance of residence time in the sorption of uranium by the MST. As with strontium, there was a reduction in uranium DF that is very noticeable for CSTR 1 in the 64- to 72-h time frame and for CSTR 2 in the 68- to 72-h time frame. For CSTR 2, the DF decreased from 3.5 to 2.5, and for CSTR 1, from 2.9 to 1.5. As mentioned above, the loss of MST flow to CSTR 1 caused the problem. Figure 21 compares the concentration of nonsorbed uranium in the vessels as a function of test time. 


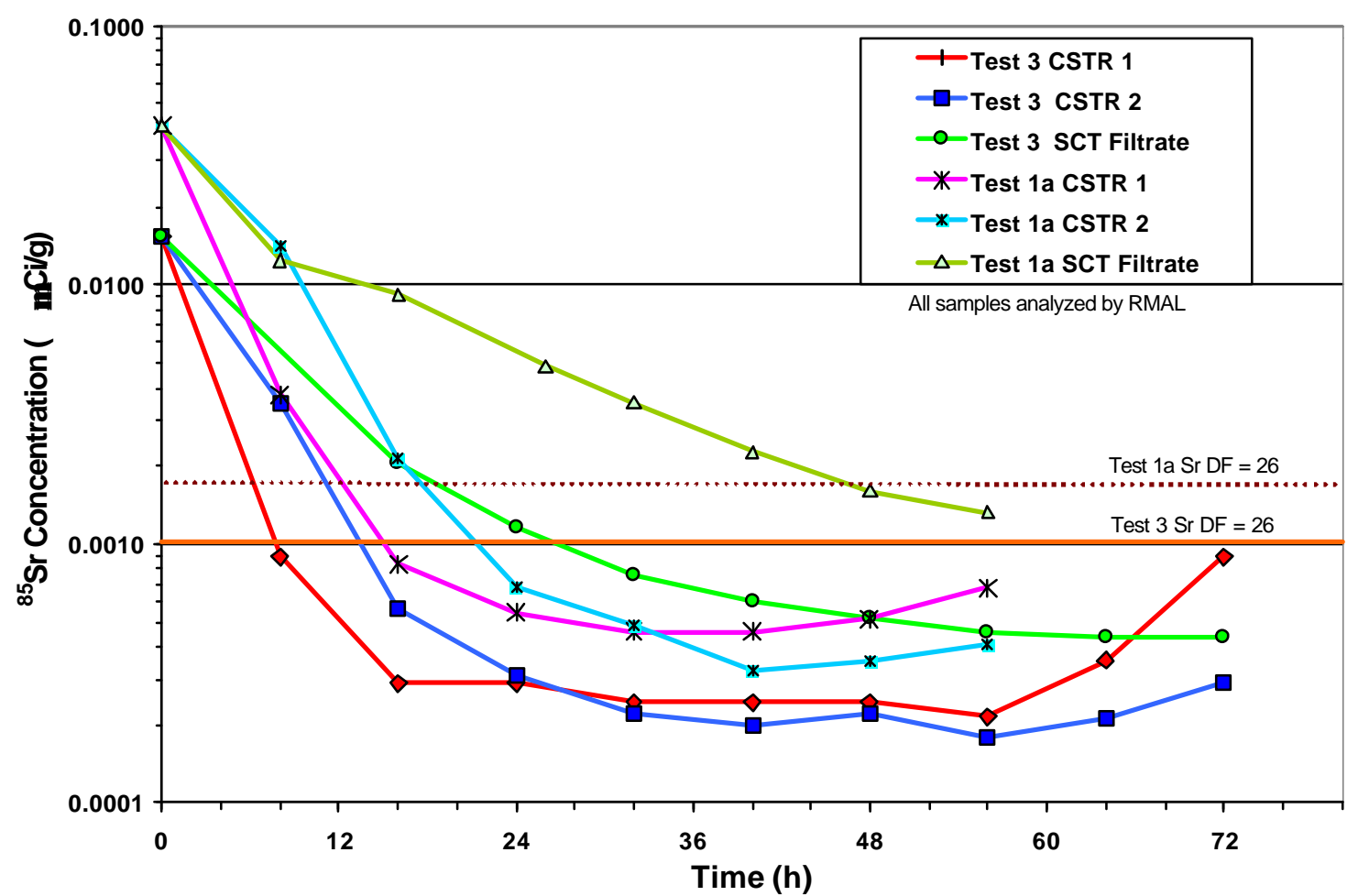

Fig. 17. Strontium concentrations during Tests 1a and 3 .

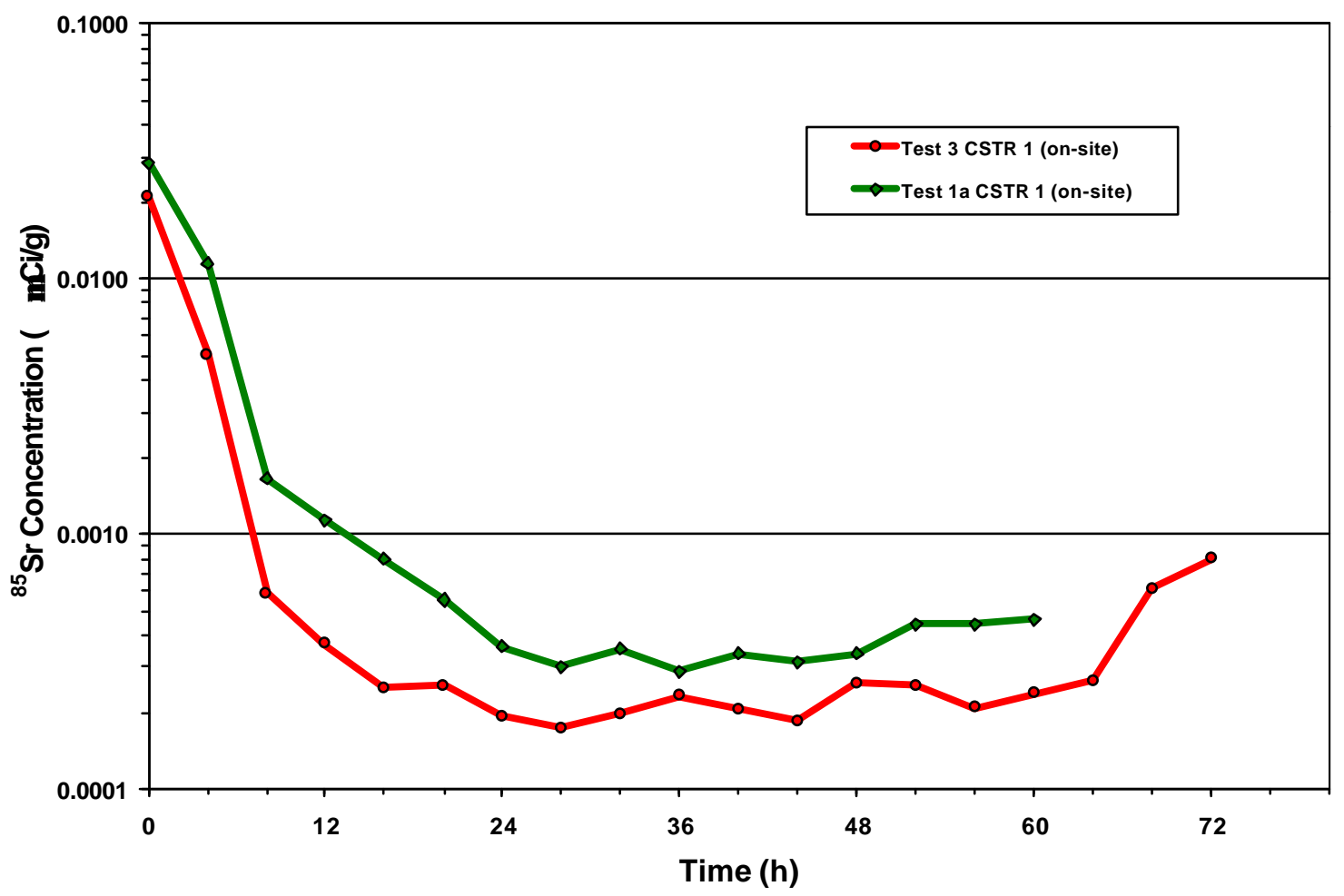

Fig. 18. Strontium concentrations after CSTR 1 in Tests $1 a$ and 3. 


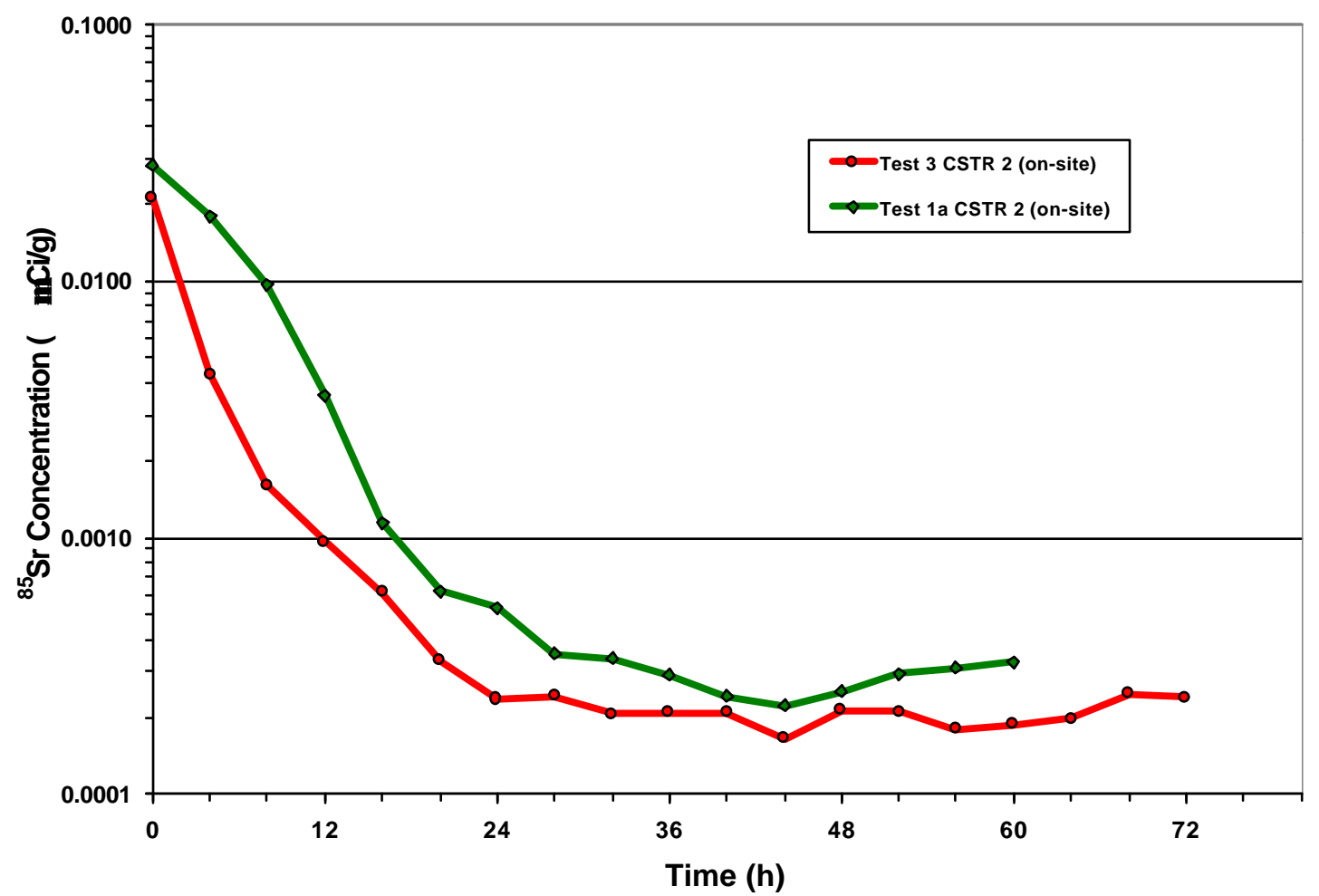

Fig. 19. Strontium concentrations after CSTR 2 in Tests 1 and 3.

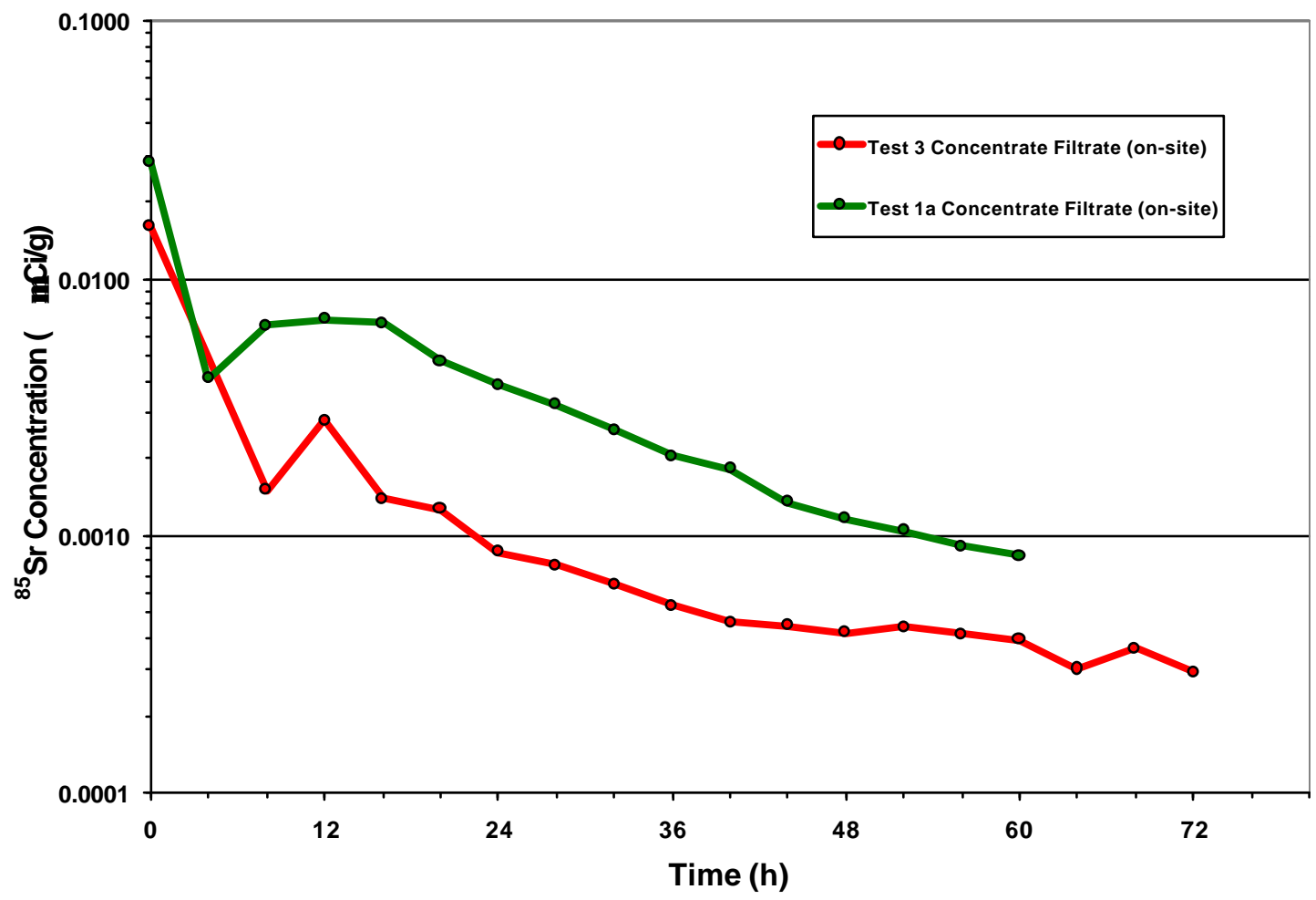

Fig. 20. Strontium concentrations in concentrate filtrate in Tests 1a and 3. 


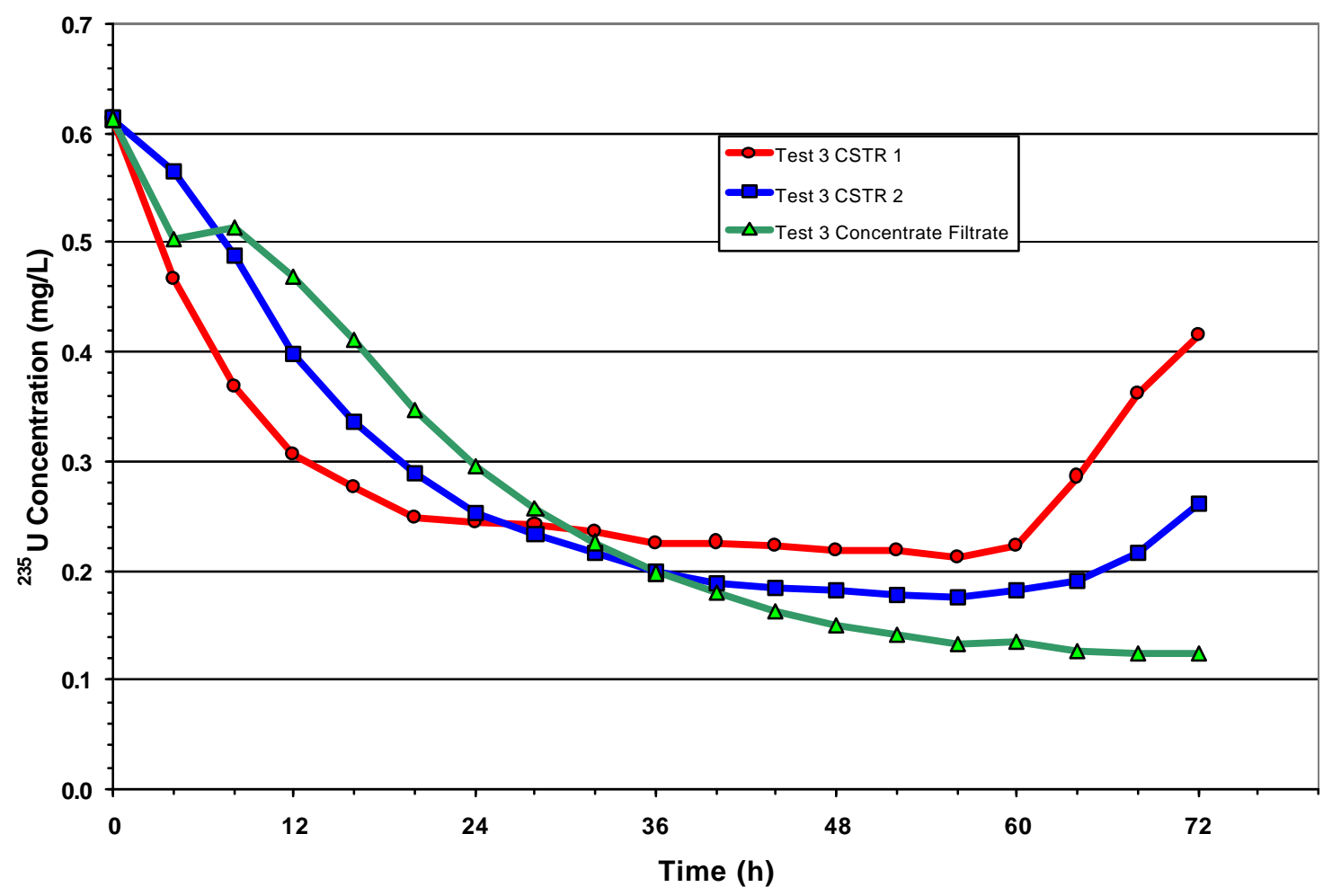

Fig. 21. Comparison of uranium concentrations during Test 3.

Figure 22 compares the uranium results obtained in Tests 3 and 1a. After 60-h testing, the Test 3 DFs were 5 in the SCT, 3.5 in CSTR 2, and 2.3 in CSTR 1--compared with DFs of 3, 2.5, and 2.3 for Test 1a. The removal was better in Test 3 even though the IITB52 was used. It is speculated that the increased mixer speed used in the process vessels in Test 3 enhanced the removal of uranium.

\subsubsection{HPLC Analyses for TPB and Decomposition Products}

RMAL analysis of the samples from all three sample points showed less than the detectable amount of 1PB, 2PB, 3PB, and phenol throughout the test. The HPLC analyses showed that no measurable NaTPB decomposition occurred during the test (i.e., no decomposition products were detected). TPB analyses are given in Figs. 23-25. TPB follows the expected course, at first falling to undetectable levels as a soluble constituent in CSTR 1 as the bulk of the potassium and cesium was being precipitated from the diluted salt feed, and then increasing to levels of 100-150 ppm soluble NaTPB when the potassium concentration was reduced to about $200 \mathrm{ppm}$.

\subsubsection{ICP-AES Analyses for Potassium and Boron}

Figures 23-25 show the RMAL results for the potassium, boron, and NaTPB for the three sample points. The potassium begins falling when TPB is added to CSTR 1 . The boron analysis shows that the amount of boron is dependent on, and agrees with, the amount of soluble TPB present, as expected. If decomposition were taking place, the amount of boron would be greater than the amount associated with the soluble TPB. 


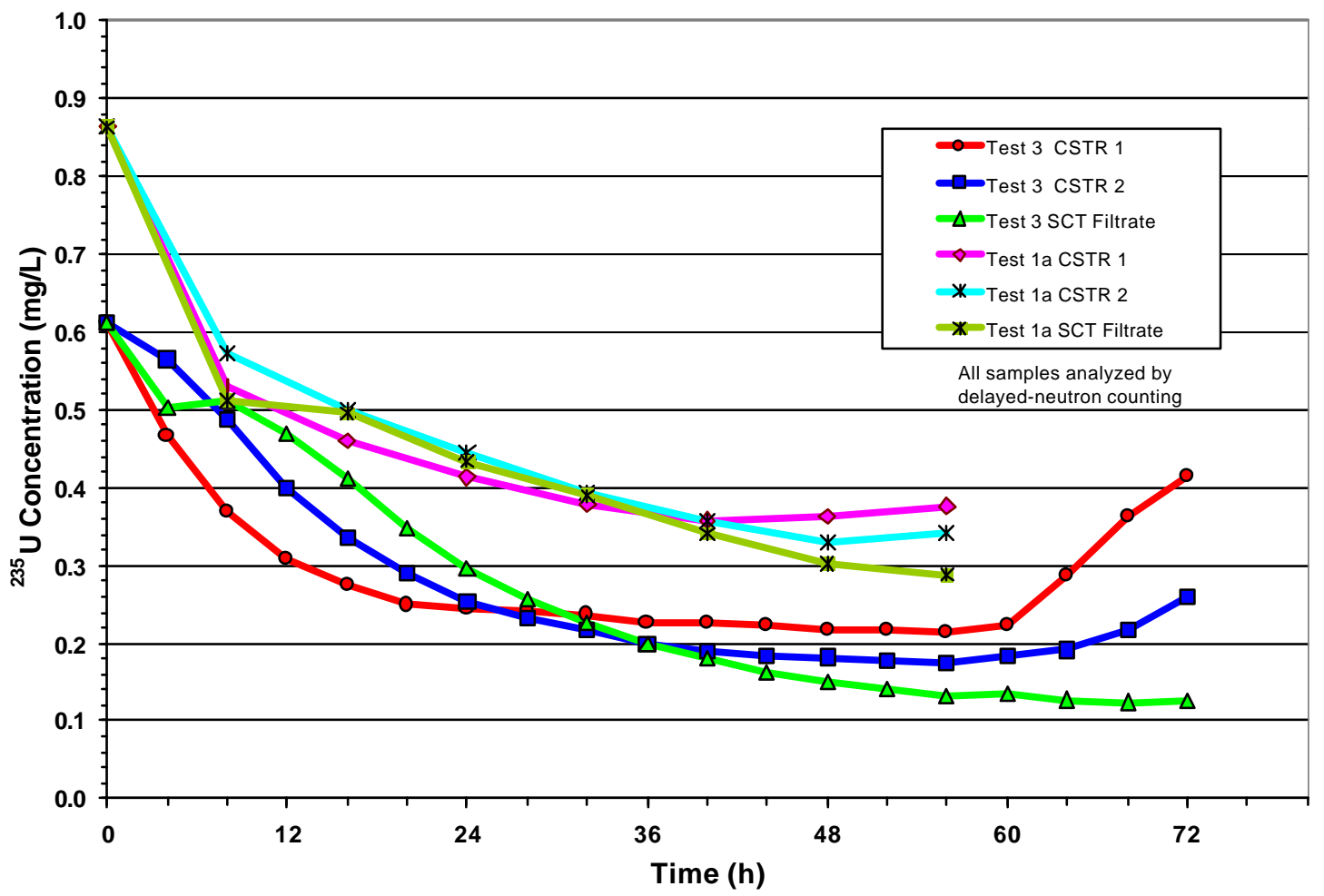

Fig. 22. Comparison of uranium concentrations during Tests 1a and 3.

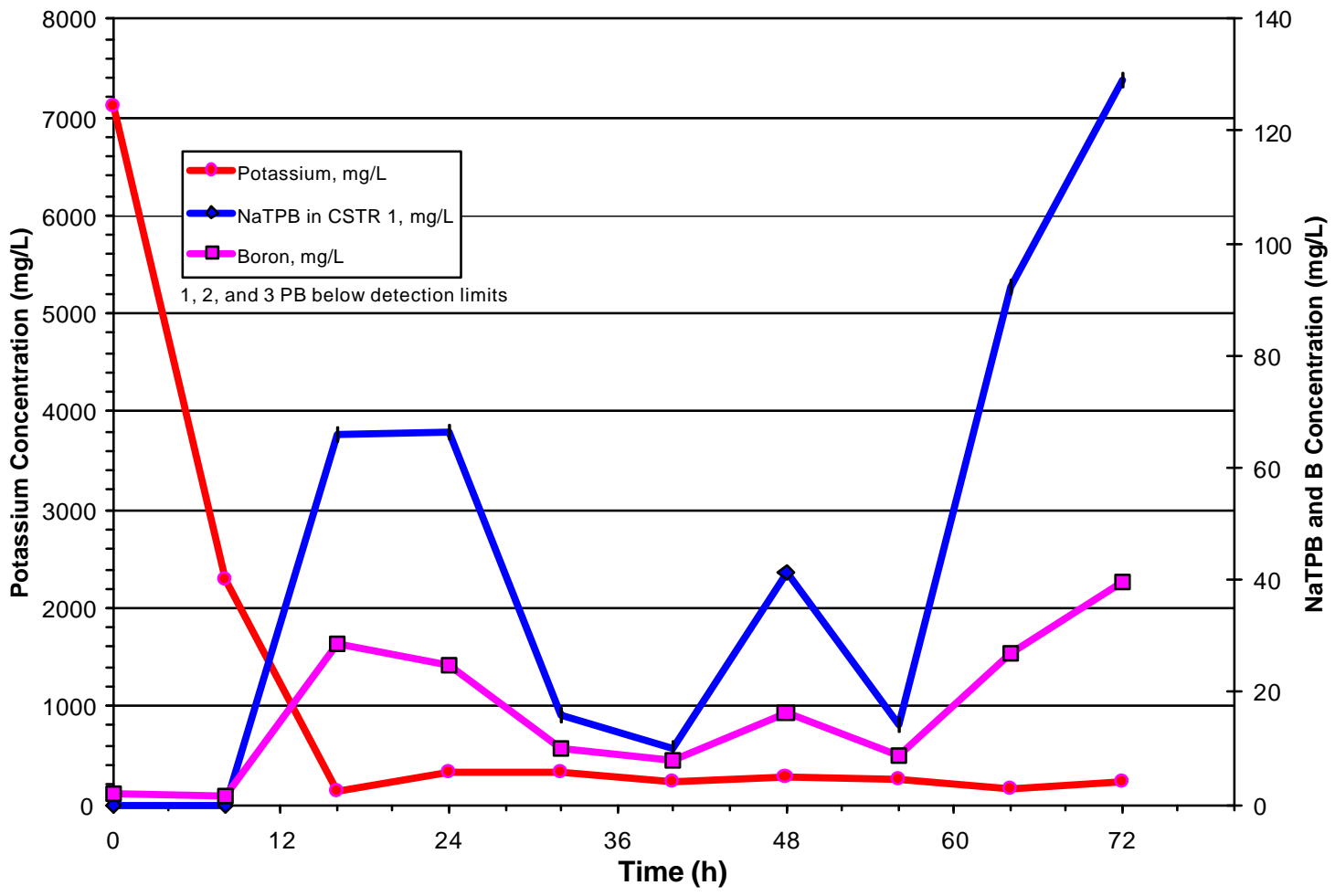

Fig. 23. Potassium, boron, and NaTPB after CSTR 1 during Test 3. 


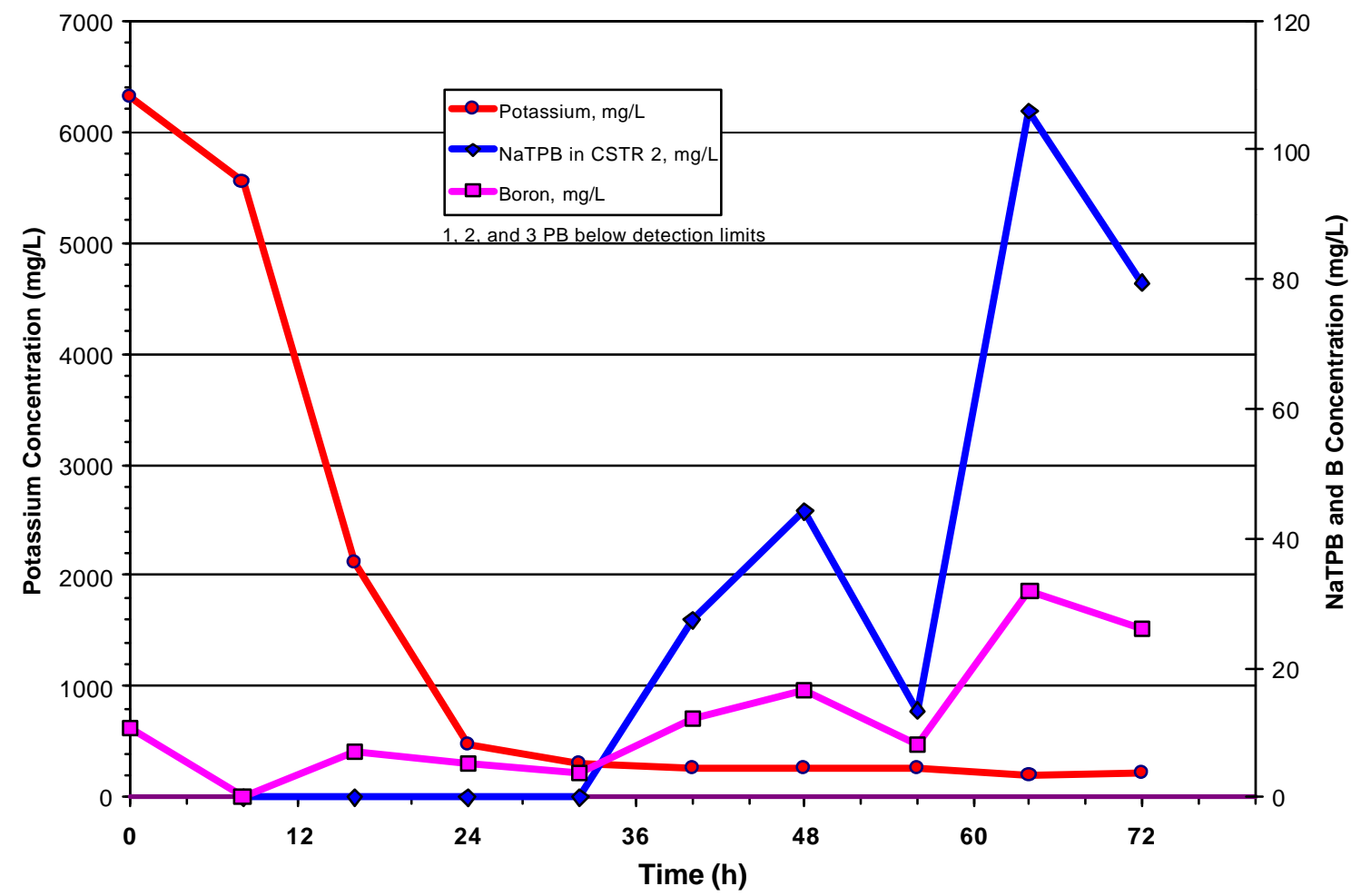

Fig. 24. Potassium, boron, and NaTPB after CSTR 2 during Test 3.

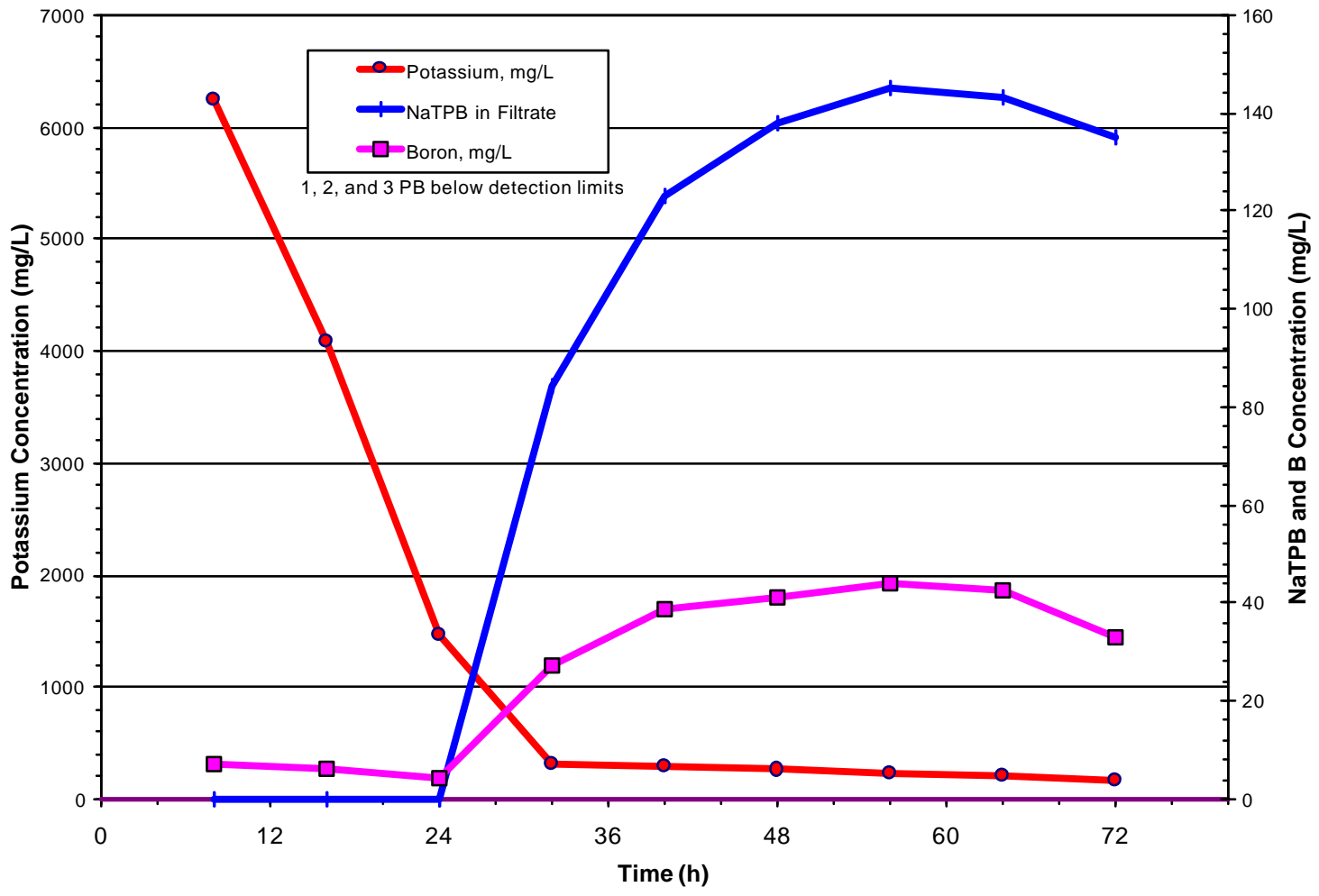

Fig. 25. Potassium, boron, and NaTPB in concentrate filtrate during Test 3. 


\subsubsection{Material Balances}

The record of flow rate versus time for the process fluids used and produced in the CSTR system is shown in Figs. 26 and 27. Figure 26 shows the cumulative average flow rates for the several feeds. Additional information on the feed to the system is shown in Fig. 27. It shows the cumulative totals of each feed stream during the course of the test. The data indicates acceptable control of process feeds and smooth operation of the slurry concentrating system.

\subsection{SUBSYSTEMS OPERATION}

Process control for this test was sufficient to provide meaningful process performance data. Even with the high mixing speeds of $1200 \mathrm{rpm}$ (shown to cause foam as noted in Sect. 2.1) in the process vessels (compared to the normal $600 \mathrm{rpm}$ in previous tests in which no foam was seen), the process control in Test 3 was very good. Because the IITB52 antifoam performed well, foam formation was minimal. The solution density for the concentration system, as measured by the Coriolis mass flow measurement system, decreased in the normal manner during concentration from about $1.2 \mathrm{~g} / \mathrm{mL}$ at the start to about 1.15 at the end of concentration. There was no significant reduction in density caused by the entrainment of foam in the slurry (foam would reduce the density by $0.2-0.5 \mathrm{~g} / \mathrm{mL}$ and would be pressure sensitive). The radar probe in the salt feed tank functioned properly and provided good crosscheck measurements of the salt feed rate to CSTR 1 by comparing tank volume versus time to the instantaneous flow rate data. The differential pressure level probe (Bindicator) in the SCT operated with no problems. This level monitoring system was a significant improvement over the previous type of level sensor, a guided wave radar probe that plugged with slurry during operation and quit operating. The first four hours of slurry concentration were run using flow control, a less desirable method from a process control standpoint. When it was clear that the Bindicator monitor was operating reliably, the slurry concentration operation was switched to level control for the remainder of the test.

The larger trim in the filtrate-flow control valve in the cross-flow filtration loop (replacing the smaller trim used in the previous tests) provided stable and trouble-free operations at lower filtrate pressure $(20 \mathrm{psi})$. This improvement also resulted in a lower heat load in the slurry concentrating system because the progressive-cavity filtration loop pump could be operated at a lower speed. The needed flow rates were obtained at 60 to $70 \%$ valve opening at 3- to 6-psi transmembrane pressure (pressure difference between the slurry concentrate and filtrate). Backpulsing the cross-flow filter to reduce transmembrane pressure was not necessary during the test. However, one back-pulse operation was performed after the run was completed to empty the backpulse pressure vessel.

Only a few difficulties were encountered at startup in achieving proper operation of all the feed systems. The first problem was caused by a loose fitting in the salt feed line that was revealed by air bubbles in the line while the salt feed was being pumped from the feed tanks in Hot Cell C to CSTR 1. This was corrected by replacing the plastic tubing of the salt feed pump (peristaltic type) and tightening the line fittings. When the NaTPB feed pump was started, no flow was seen (indicated by no change in the mass of the balance that the NaTPB tank sat on). It was assumed that the line was plugged at the cell wall or inside the cell. To correct the problem, the NaTPB line outside the hot cell was attached with a tee fitting to the simulated recycle wash water line at the wall of the hot cell. All the NaTPB was pumped into CSTR 1 via the recycle wash water line. It was later determined that the pumping difficulty was caused by an air bubble that became lodged in the pump head of the FMI positive displacement pump head used for the NaTPB.

A problem with the MST slurry feed occurred about 8-12 h before the test ended. Apparent settling of the slurry in the feed line caused overpressuring of the line. The excessive pressure caused the flexible feed line to breach at a location not clearly visible to the operators. The problem was not detected until the test was terminated and the valve at the hot cell wall was closed. 


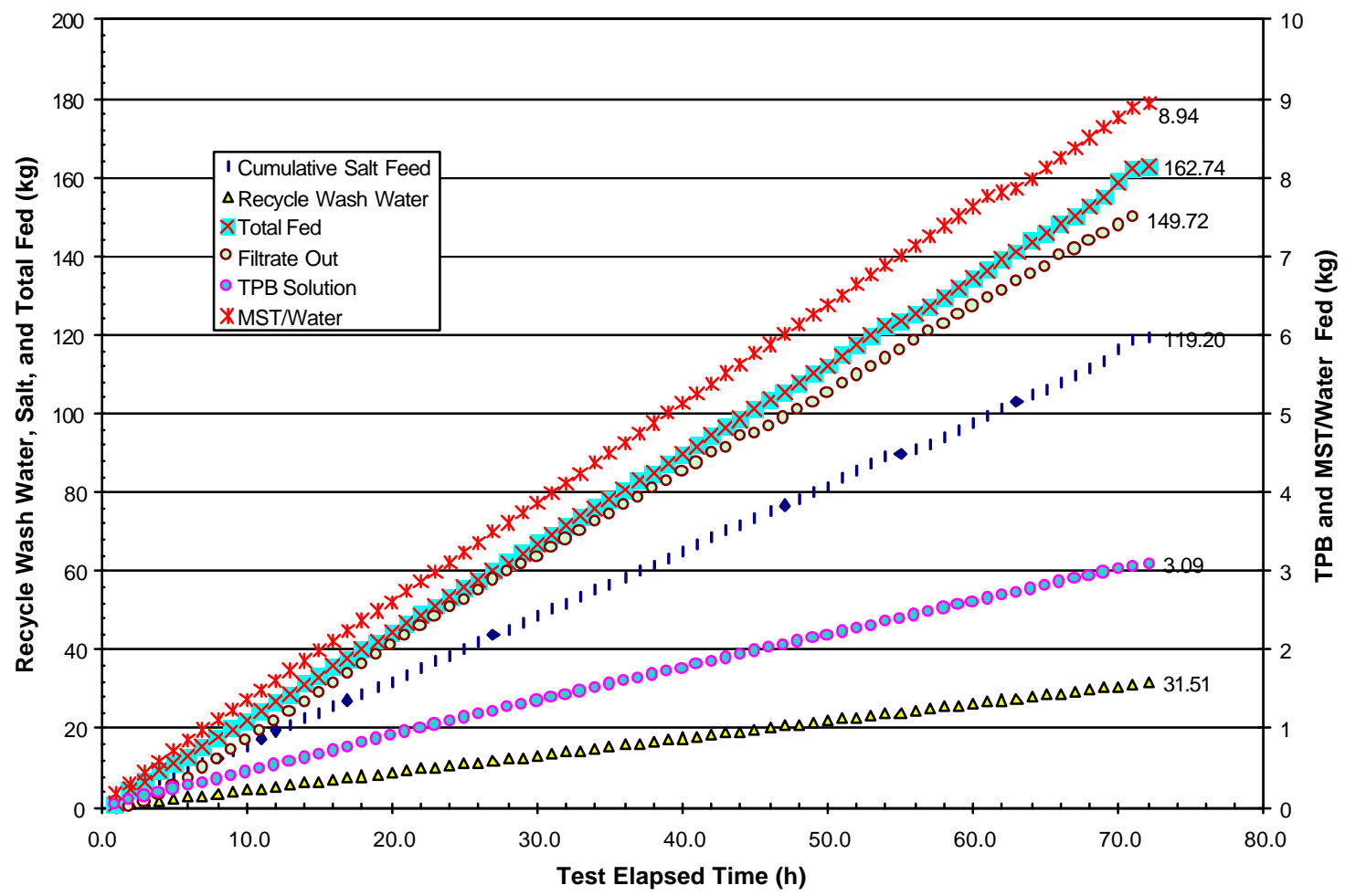

Fig. 26. Plot of the average feed rates of process fluids for Test 3.

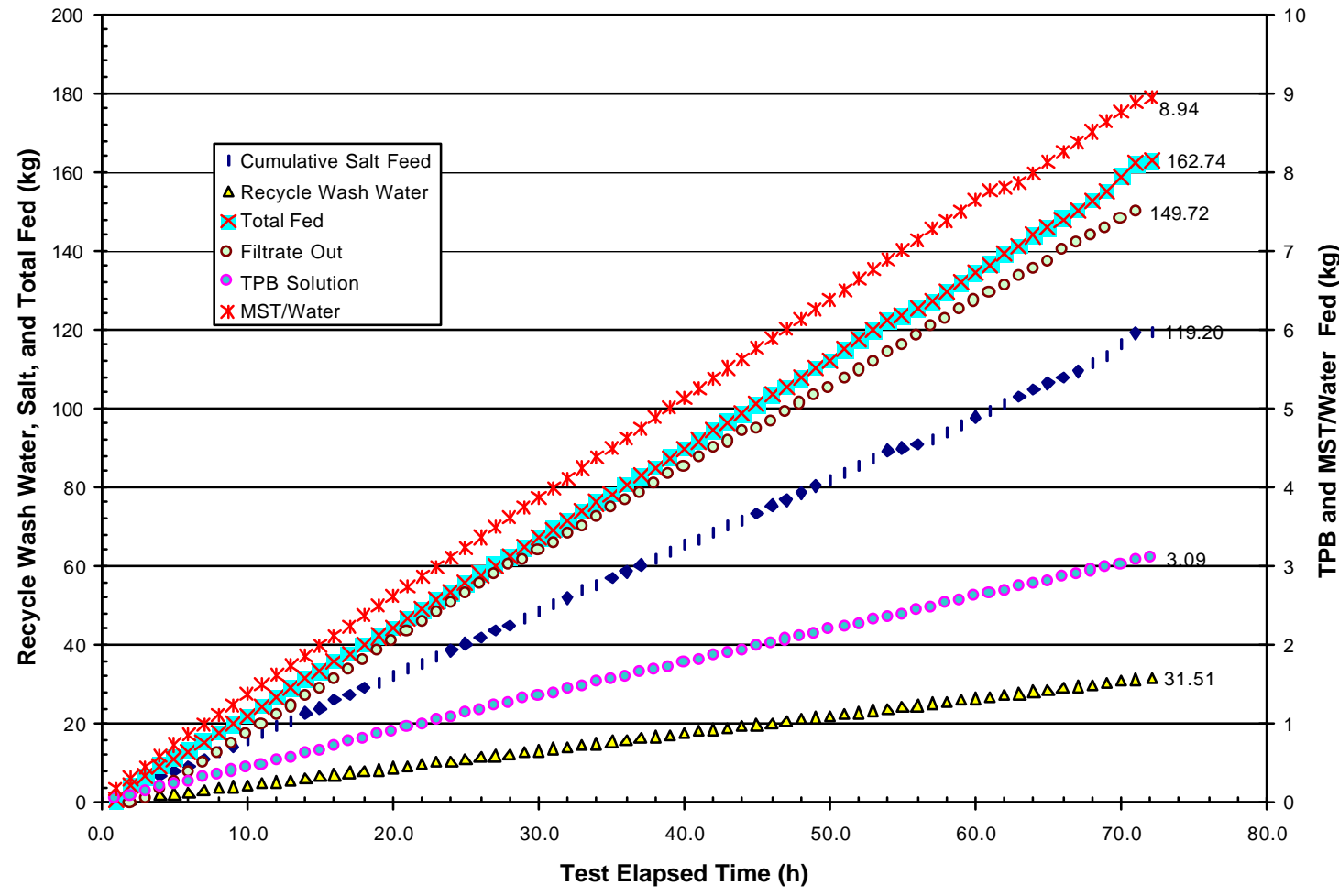

Fig. 27. Plot of the cumulative feed totals for materials fed to CSTR 1 during Test 3. 
Analyses of ${ }^{85} \mathrm{Sr}$ and ${ }^{235} \mathrm{U}$ in the CSTR 1 filtrates showed decreases in DFs of those isotopes at the end of the test, which is consistent with loss of the needed MST concentration. The test was actually terminated $8 \mathrm{~h}$ earlier than planned due to the exhausted supply of simulant feed. The feed was exhausted somewhat prematurely because the dip tube for the feed tank did not reach the design depth in the tank. It was found in a later inspection of the tank that the dip tube was inadvertently bent upward during the movement of the feed system equipment from Hot Cell A to Hot Cell C. This premature shutdown did not impact the value of the test results in any way. Repairs were made prior to conducting additional tests. Aside from the feed problems previously noted, the overall equipment performance for Test 3 was very good and the feed rates and totals were all satisfactory.

\subsection{SLURRY WASHING}

All the concentrated slurry produced during the test was transferred to the Slurry Washing Tank (SWT) and washed with deionized water to evaluate the ability to recover unreacted NaTPB. Deionized water was pumped into the SWT at a rate of $15 \mathrm{~mL} / \mathrm{min}$. The concentrated slurry was washed until the nitrite concentration of the cross-flow filter filtrate was about $0.0157 \mathrm{M}$, or $721 \mathrm{mg} / \mathrm{L}$ (see Table 5). The slurry solids were stirred at 1200 to $1250 \mathrm{rpm}$ at $25^{\circ} \mathrm{C}$ while pumping IITB52 into the tank at a rate of $0.00312 \mathrm{~mL} / \mathrm{min}$. The vapor space of the SWT was purged with nitrogen gas during the washing process. Since the washing process was not conducted under closed-looped test conditions in which the slurry would be continuously washed, the solids were initially washed in three 8-h steps $(\sim 7.2 \mathrm{~L}$ of water during $8 \mathrm{~h}$ ). This allowed for two overnight mixing periods, providing additional time for dissolution without increasing the volume of recycle water. For maximal dissolution of the NaTPB solids, the nitrite concentration of the slurry wash in the SWT should be about $0.065 M$ for the second overnight mixing period (the actual nitrite concentration was $0.078 M$ after $16 \mathrm{~h}$ and $0.031 M$ after $24 \mathrm{~h}$ of washing). A sample of the cross-flow filtrate was analyzed for NaTPB after the three 8-h steps of washing were complete. The nitrite had not reached $0.01 M$ after $24 \mathrm{~h}$ of washing; therefore, the washing was continued an additional $8 \mathrm{~h}$ when the nitrite concentration reached $0.0157 \mathrm{M}$. After further analysis was completed, the washwater was reserved for use in Test 4 initial startup operations, and additional NaTPB $(9.9 \mathrm{~g})$ was added to the $28.8 \mathrm{~L}$ of recycle wash water to obtain the needed concentration of $0.033 \mathrm{~mol} / \mathrm{L}$ NaTPB for use in Test 4.

Table 5. Results for Test 3 slurry washing at $15 \mathrm{~mL} / \mathrm{min}$

\begin{tabular}{ccccc}
\hline $\begin{array}{c}\text { Washing } \\
\text { volume } \\
(\mathrm{L})\end{array}$ & $\begin{array}{c}\text { Washing time } \\
(\mathrm{h})\end{array}$ & $\begin{array}{c}\text { Recycle wash water } \\
\text { sample ID }\end{array}$ & $\begin{array}{c}\mathrm{NO}_{2} \\
(\mathrm{mg} / \mathrm{L})^{a}\end{array}$ & $\begin{array}{c}\mathrm{NaTPB}^{a} \\
(\mathrm{mg} / \mathrm{L})\end{array}$ \\
\hline 0 & 0 & $00 \mathrm{~T} 3 \mathrm{~W}-1$ & 20800 & 267 \\
3.6 & 4 & $04 \mathrm{~T} 3 \mathrm{~W}-2$ & 14400 & 510 \\
7.2 & 8 & $08 \mathrm{~T} 3 \mathrm{~W}-3$ & 9130 & 850 \\
10.8 & 12 & $12 \mathrm{~T} 3 \mathrm{~W}-4$ & 6470 & 1300 \\
14.4 & 16 & $16 \mathrm{~T} 3 \mathrm{~W}-5$ & 3630 & 1140 \\
18.0 & 20 & $20 \mathrm{~T} 3 \mathrm{~W}-6$ & 1800 & 1120 \\
21.6 & 24 & $24 \mathrm{~T} 3 \mathrm{~W}-7$ & 1440 & 948 \\
25.2 & 28 & $28 \mathrm{~T} 3 \mathrm{~W}-8$ & 971 & 1440 \\
$\frac{28.8}{\text { Overall tank sample }}$ & $\underline{32}$ & $\underline{36 \mathrm{~T} 3 \mathrm{~W}-9}$ & $\underline{721}$ & $\underline{1260}$ \\
\hline
\end{tabular}

${ }^{a}$ Analyzed by RMAL. 
The composite recycle wash water in the Recycle Wash Water Tank was thoroughly mixed and a sample taken for analysis. RMAL determined that the NaTPB was only $0.0033 \mathrm{~mol} / \mathrm{L}$. Because of the method of starting the test, in which the CSTRs were filled with the $4.7 \mathrm{M} \mathrm{Na}^{+}$water diluted salt feed (also $3 \mathrm{~L}$ in the SCT), a large fraction of the TPB was precipitated as potassium tetraphenylborate (KTPB), leaving only $0.33 \mathrm{~mol}$ of excess TPB in the slurry concentrating system available for water washing recovery. If all the TPB precipitated as NaTPB had dissolved in the $28.8 \mathrm{~L}$ of wash water, the concentration would have been $0.011 \mathrm{~mol} / \mathrm{L}$. This would have been only about $35 \%$ of the required $0.033 \mathrm{~mol} / \mathrm{L}$. About $0.095 \mathrm{~mol}$ of TPB was actually recovered, providing a concentration $0.0033 \mathrm{~mol} / \mathrm{L}$. This was $29 \%$ of the available TPB. The profiles of nitrate and NaTPB concentrations as a function of wash volume are shown in Fig. 28. The data indicates that NaTPB concentration reaches a consistent level in the range of $948-1440 \mathrm{mg} / \mathrm{L}(0.0028-0.0042 \mathrm{~mol} / \mathrm{L})$ in the washwater at a wash volume of $10 \mathrm{~L}$ and remains at this level during the entire wash cycle. This indicates that additional washing could recover additional quantities of NaTPB, but at the expense of generating washwater quantities greater than the amount that can be recycled efficiently. To obtain the desired recycle wash water TPB concentration of $0.033 \mathrm{~mol} / \mathrm{L}$, only $10 \mathrm{~L}$ of deionized water could have been used in the washing process.

Table 6 compared the washing results in Test 3 with those of the previous CSTR tests, which were also started up by first filling the CSTRs with the $4.7 M \mathrm{Na}^{+}$water-diluted salt feed and adding about $3 \mathrm{~L}$ in the SCT. In Test 1a, the concentrated slurry was washed at a rate of $10 \mathrm{~mL} / \mathrm{min}$, and $12.3 \mathrm{~L}$ of wash water was collected. The concentrated slurry in Test 1a was mixed at 600 to $700 \mathrm{rpm}$ at $25^{\circ} \mathrm{C}$ and the antifoam IITB52 was not used. Twelve per cent of the available TPB $(0.048 \mathrm{~mol})$ was recovered. However, less wash water was used and the TPB concentration was $0.0047 \mathrm{~mol} / \mathrm{L}$, which was higher than the TPB concentration of $0.0033 \mathrm{~mol} / \mathrm{L}$ for the Test 3 wash water. None of the water washes in Test 2 (also stirred at 600-700 rpm at $25^{\circ} \mathrm{C}$ with no antifoam IITB52) recovered more than $20 \%$ of the available TPB. The Test 2, Cycle \#4 batch may have recovered more TPB if the wash had continued for the same volume as the Test 3 wash, possibly twice as much as shown. If Test 3 wash had been stopped at about $14 \mathrm{~L}$, the amount of TPB recovered would have been about half, as seen in Fig. 28. Although the recoveries were generally low in every case, the trends of these data in Table 5 show the importance of the washing parameters. These low concentrations of NaTPB in the wash water may be indicative of inefficient mixing that caused poor mass transfer and NaTPB dissolution rates at the lower stirrer speeds. Based on the results in Table 6, it is probable that the higher mixer speed used in test 3 could have enhanced TPB recovery.

The solubilities of the TPB precipitates of $\mathrm{Na}, \mathrm{K}$, and cesium are the basis for the utility of the STTP. ${ }^{6,7}$ TPB dissolution behavior was studied in laboratory-scale tests with IITB52 antifoam at Savannah River. ${ }^{8}$ Several tests of TPB dissolution were conducted in which slurries that had been produced by precipitation of a standard $4.7 M$ sodium simulant with $0.0125 M$ potassium were concentrated to $10 \mathrm{wt} \%$ using a cross-flow filter system. Laboratory batch mixing tests were performed for one slurry without antifoam and three others with three different antifoams, one of which was IITB52. The results showed that about $60 \%$ of the excess TPB was recovered, and a maximum concentration of NaTPB in the wash water was $0.041 M$. When IITB52 was used, only $12.7 \%$ of the excess NaTPB was removed and the maximum NaTPB concentration was $0.0058 M$. These large differences between the tests with and without antifoam were not observed in the 20-L system in Tests 1a and 3 in which the slurry produced for washing had a slightly higher concentration of KTPB (less NaTPB to dissolve) due to the method of startup. 
Table 6. NaTPB recovery in the slurry washing process in CSTR tests

\begin{tabular}{ccccccccc}
\hline $\begin{array}{c}\text { Test } \\
\text { No. }\end{array}$ & $\begin{array}{c}\text { Wash } \\
\text { cycle }\end{array}$ & $\begin{array}{c}\text { Time } \\
(\mathrm{h})\end{array}$ & $\begin{array}{c}\text { Wash } \\
\text { rate } \\
(\mathrm{mL} / \mathrm{min})\end{array}$ & $\begin{array}{c}\text { Available } \\
\mathrm{TPB}^{a} \\
(\mathrm{~mol})\end{array}$ & $\begin{array}{c}\mathrm{RWW}^{b} \\
(\mathrm{~L})\end{array}$ & $\begin{array}{c}\text { TPB } \\
\text { recovered } \\
(\mathrm{mol})\end{array}$ & $\begin{array}{c}\mathrm{TPB}^{c} \\
(\mathrm{~mol} / \mathrm{L})\end{array}$ & $\begin{array}{c}\text { Percent } \\
\text { recovered }\end{array}$ \\
\hline $1 \mathrm{a}$ & $1^{e}$ & 16 & 10 & 0.48 & 12.3 & 0.058 & 0.0047 & 12 \\
\hline 2 & 1 & 31 & 10 & 0.86 & 18.6 & 0.072 & 0.0039 & 9 \\
2 & 2 & 28 & 15 & 0.63 & 25 & 0.115 & 0.0046 & 18 \\
2 & 3 & 43 & 8 & 0.76 & 20.6 & 0.148 & 0.0072 & 19 \\
2 & 4 & 44 & 5 & 0.69 & 13.2 & 0.138 & 0.0105 & 20 \\
\hline 3 & $1^{j}$ & 32 & 15 & 0.33 & 28.8 & 0.095 & 0.0033 & 29 \\
\hline
\end{tabular}

${ }^{a}$ Moles of excess TPB as NaTPB in batch available to be dissolved by water washing.

${ }^{b} \mathrm{RWW}=$ recycle wash water.

${ }^{c}$ Testing goal was to obtain enough TBP in recycle wash water to provide a $60 \%$ excess $(\sim 0.033 \mathrm{~mol} / \mathrm{L})$.

${ }^{d}$ (mol TPB recovered)/(mol available TPB in batch).

${ }^{e}$ Recycle wash water used in Test 2.

${ }^{f}$ Recycle wash water to be used in Test 4.

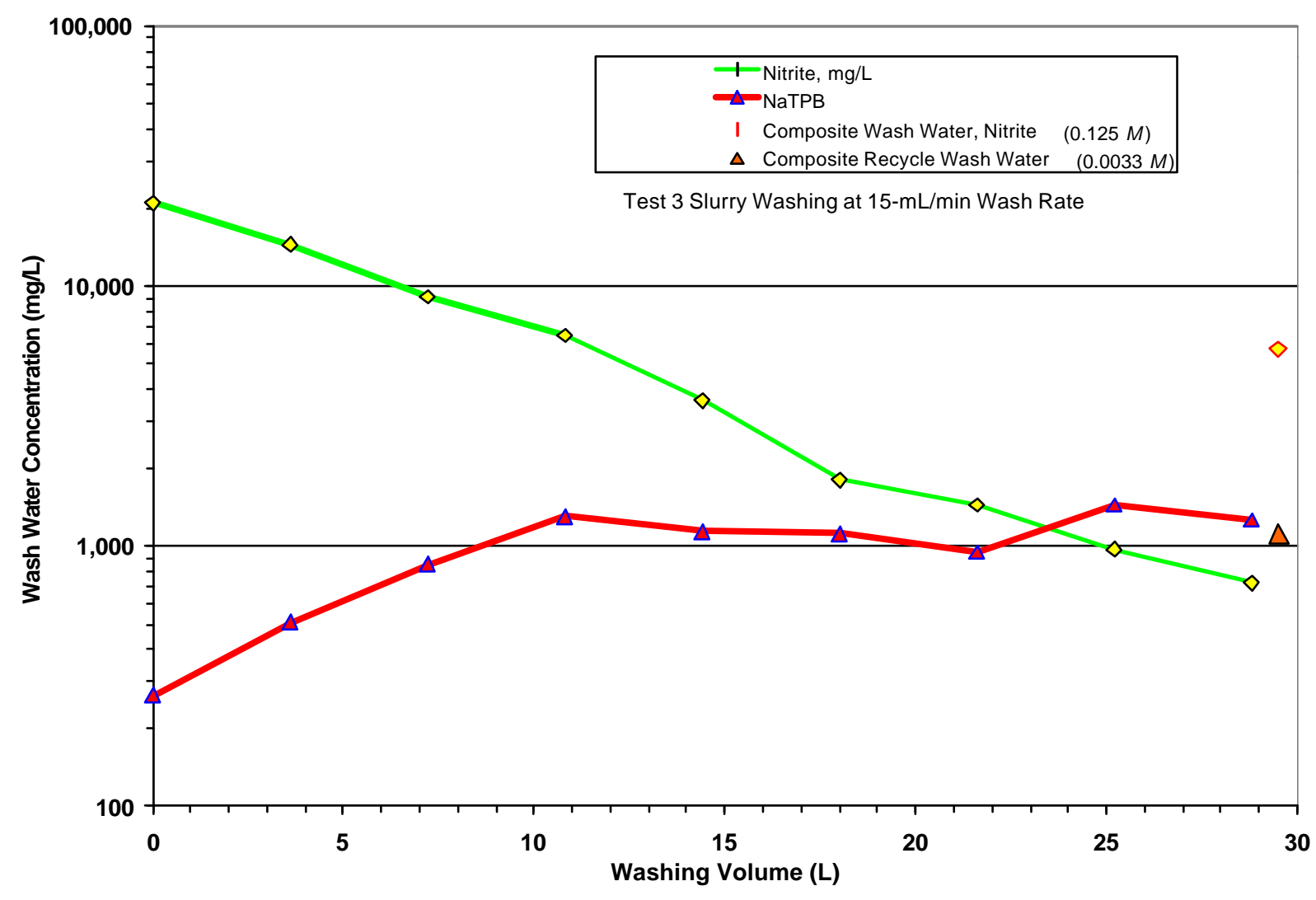

Fig. 28. Nitrite and TPB concentrations during Test 3 slurry washing. 


\section{CONCLUSIONS}

Test 3 was a 72-h test with approximately nine volume turnovers that was conducted with the objectives of determining the effectiveness of an improved antifoam (IITB52) in minimizing foam formation and to determine if its presence had a deleterious effect on the removal of cesium, strontium, and uranium from simulated waste. To more aggressively test the antifoam, the slurry in each vessel was mixed at 1200 to $1250 \mathrm{rpm}$ while maintaining the temperature at $25^{\circ} \mathrm{C}$. This rate of mixing was found to cause heavy foam formation in a control test that was conducted prior to Test 3 . There was no evidence of excessive foam formation in Test 3, as indicated by the lack of foam in the analytical samples of slurries taken, by the absence of foam in the clear plastic slurry transfer lines between the vessels, and by lack of any significant decrease the slurry density measurements in the slurry concentration loop. More than $92 \mathrm{~L}$ of radioactive, simulated waste was treated, $\sim 135 \mathrm{~L}$ of decontaminated filtrate was collected, and $\sim 6.5 \mathrm{~L}>9 \mathrm{wt} \%$ slurry concentrate was collected and washed.

The decontamination goal of obtaining a DF of 40,000 or $99.998 \%$ removal was exceeded in all process vessels, indicating that the IITB52 did not impact cesium removal performance. $\mathrm{A} \mathrm{DF}_{\mathrm{Cs}}$ of 37,000 was obtained in the SCT in about $32 \mathrm{~h}$. It subsequently fluctuated between 21,000 and 59,000 and was the highest at the end of the test. $\mathrm{A} \mathrm{DF}_{\mathrm{Cs}}$ of 40,000 was obtained in $14 \mathrm{~h} \mathrm{CSTR} 1$ and afterward ranged between 41,000 and 270,000. It took about $32 \mathrm{~h}$ for the DF to reach 40,000 in CSTR 2, and for the remainder of the test, the DF ranged from 49,000 to 77,000. In comparing the cesium concentration versus time profiles for previous tests where the antifoam was not used, there was no clear evidence that the rate of cesium removal was adversely impacted by the antifoam used in this test.

The IITB52 had no impact on the sorption of strontium and uranium by the MST. A DF of 30 was obtained for strontium in the SCT in about $24 \mathrm{~h}$, and near the end of the test, it was $100 . \mathrm{A} \mathrm{DF}_{\mathrm{Sr}}$ of 26 was needed to reach the WAC standard for saltstone. A DF of 5 for uranium in the SCT was obtained at the end of the test. This is indicative that the other actinides (neptunium and plutonium) would achieve DFs that met the WAC standards for saltstone.

At the end of Test 3, the concentrated slurry in the concentrating system was transferred to the SWT and washed with deionized water to evaluate the ability to recover unreacted NaTPB. The slurry solids were stirred at 1200 to $1250 \mathrm{rpm}$ at $25^{\circ} \mathrm{C}$ while adding wash water at $15 \mathrm{~mL} / \mathrm{min}$ and pumping IITB52 into the tank at a rate of $0.00312 \mathrm{~mL} / \mathrm{min}$. A total of $28.8 \mathrm{~L}$ of wash water that had a concentration of $0.0033 \mathrm{~mol} / \mathrm{L}$ (29\% of the available TPB) was collected. This recovery was actually better that than the recovery in Test 1a and Test 2 in which only $12 \%$ and $18-20 \%$ of the available TPB was recovered, respectively, and no antifoam was used. It does not appear that the antifoam interfered with the dissolution of the precipitated NaTPB. The higher mixing rate in Test 3 may have contributed to the larger fraction of TPB that was recovered. There is an obvious problem in recovering available TPB by water washing that needs to be experimentally examined more closely.

Problems with the operation of the equipment during the test were minimal, especially in the slurry concentration cross-flow filter system. Process modifications and improved control and data acquisition systems improved the overall operating performance of the equipment. The primary problems involved the feed systems. However, these process upsets were dealt with quickly and efficiently by the operating personnel without significant impact on the overall process or the value of the operating data. 


\section{REFERENCES}

1. D. D. Lee and J. L. Collins, Continuous-Flow Stirred-Tank Reactor 20-L Demonstration Test: Final Report, ORNL/TM-1999/234, February 2000.

2. D. D. Lee, Test Plan For CSTR Test 3, CERS/SR/TPB/010, Sept. 9, 2000.

3. J. L. Collins and D. D. Lee, Preparation of Simulated Waste Solutions for CSTR Tests, CERS/SR/TPB/005, Rev. 3, Oct. 9, 2000.

4. J. L. Collins, Sampling Plan and Procedure, CERS/SR/TPB/006, Rev. 1, Aug. 2, 2000.

5. T. R. Tipton, Instrumentation Data Sheets and Loop I/O Database, CERS/SRS/TPB/009, Rev. 2, Aug. 04, 2000.

6. R. A. Peterson and J. O. Burgess, Co-precipitation and Solubility Studies of Cesium, Potassium, and Sodium Tetraphenylborate, WSRC-TR-99-00216, June 24, 1999.

7. S. M. Serkiz, J. D. Ginn, and A. R. Jurgensen, Tetraphenylborate Solubility in High Ionic Strength Salt Solutions, WSRC-TR98-00103, Rev. 0, Apr. 3, 1998.

8. M. A. Baich, D. P. Lambert, and P. R. Monson, Laboratory Scale Antifoam Studies for the STTPB Process (U), WSRC-TR-2000-00261, Rev. 0, Oct. 24, 2000. 

ORNL/TM-2000/300

\section{INTERNAL DISTRIBUTION}

$\begin{aligned} \text { 1. } & \text { K. K. Anderson } \\ 2 . & \text { P. V. Bonnesen } \\ 3 . & \text { D. A. Bostick } \\ 4-8 . & \text { J. L. Collins } \\ 9 . & \text { B. S. Evans } \\ 10 . & \text { R. D. Hunt } \\ 11 . & \text { H. L. Jennings } \\ 12 . & \text { R. T. Jubin } \\ 13-15 . & \text { T. E. Kent } \\ 16 . & \text { L. Klatt } \\ 17-21 . & \text { D. D. Lee }\end{aligned}$

22. C. P. McGinnis

23. L. E. McNeese

24. S. A. Richardson

25. S. M. Robinson

26. P. A. Taylor

27. T. R. Travis

28-30. J. F. Walker

31. T. D. Welch

32. ORNL Central Research Library

33. Laboratory Records, RC

34. Laboratory Records, OSTI

\section{EXTERNAL DISTRIBUTION}

35. M. J. Barnes, Westinghouse Savannah River Company, P.O. Box 616, 773-A, Room B112, Aiken, SC 29808

36. J. M. Boncella, Dept. of Chemistry and Center for Catalysis, University of Florida, Gainesville, FL 32611-7200

37. J. T. Carter, Westinghouse Savannah River Company, P.O. Box 616, 704-3N, Room S151, Aiken, SC 29808

38. N. F. Chapman, Westinghouse Savannah River Company, Building 706-S, Room 103, Aiken, SC 29808

39. E. Damerow, West Valley Nuclear Services, P.O. Box 191, West Valley, NY 14171

40. I. L. Drake, Jr., U.S. Department of Energy, 10282 Rock Springs Road, West Valley, NY 14171

41. M. C. Duff, Savannah River Ecology Laboratory, University of Georgia, Aiken, SC 29802

42. H. H. Elder, Westinghouse Savannah River Company, P.O. Box 616, 704-3N, Room S151, Aiken, SC 29808

43. S. D. Fink, Westinghouse Savannah River Company, P.O. Box 616, 773-A, Room B112, Aiken, SC 29808

44. K. Gerdes, TFA Headquarters Program Lead, DOE Office of Science and Technology, 19901 Germantown Rd., 1154 Cloverleaf Building., Germantown, MD 20874-1290

45. R. L. Gilchrist, Pacific Northwest National Laboratory, P.O. Box 999, MS: K9-91, Richland, WA 99352 
46. H. D. Harmon, Tanks Focus Area Salt Processing Program, P.O. Box 616, 704-3N, Room S151, Aiken, SC 29808

47. R. A. Jacobs, Westinghouse Savannah River Company, Building 704-3N, Room S252, Aiken, SC 29808

48. J. Jewett, Numatec Hanford Corporation, P.O. Box 1970, Richland, WA 99352

49. R. T. Jones, Westinghouse Savannah River Company, P.O. Box 616, 704-3N, Room S122, Aiken, SC 29808.

50. R. B. King, Dept. of Chemistry, University of Georgia, Athens, Georgia 30602-2556

51. R. A. Kirkbride, Numatec Hanford Corporation, P.O. Box 1970, MS: H5-27, Richland, WA 99352

52. K. A. Lockie, U.S. Department of Energy, Idaho Operations Office, 750 DOE Place MS: 1145, Idaho Falls, ID 83402

53. C. S. Louie, U.S. Department of Energy, Richland Operations Office, P.O. Box 550, MSIN: B455, Richland, WA 99352

54. C. L. Leung, Westinghouse Savannah River Company, P.O. Box 616, 704-3N, Room S151, Aiken, SC 29808

55. J. W. McCullough, Jr., U.S. Department of Energy, Savannah River Operations Office, P.O. Box A, Building 704-196N, Room S431, Aiken, SC 29802

56. L. Nelson, Westinghouse Savannah River Company, P.O. Box 616, 773-A, Room-B-112, Aiken, SC 29808

57. A. Olson, Idaho National Engineering and Environmental Laboratory, Building 637, MS-5218, Idaho Falls, ID 83415-5218

58. L. M. Papouchado, Westinghouse Savannah River Company, P.O. Box 616, 773-A, Room A-263, Aiken, SC 29808

59. S. F. Piccolo, Westinghouse Savannah River Company, Building 703-H, Room: 118, Aiken, SC 29808

60. J. M. Reynolds II, U.S. Department of Energy, Savannah River Operations Office, P.O. Box A, Building 704-196N, Room S441, Aiken, SC 29802

61. J. Rindfleisch, Idaho National Engineering and Environmental Laboratory, Building 637, MS: 5218, Idaho Falls, ID 83415-5218

62. W. W. Schulz, 12704 Sandia Ridge Place NE, Albuquerque, NM 87111

63. P. C. Suggs, U.S. Department of Energy, Savannah River Operations Office, P.O. Box A, Building 704-196N, Room S431, Aiken, SC 29802 
64. S. N. Schlahta, Tanks Focus Area Salt Processing Program, P.O. Box 616, 704-3N, Room S151, Aiken, SC 29808

65. J. L. Swanson, 1318 Cottonwood, Richland, WA 99352

66. W. L. Tamosaitis, Westinghouse Savannah River Company, P.O. Box 616, 773-A, Room A-231, Aiken, SC 29808

67. L. Tavlarides, Syracuse University, Dept. of Chemical Engineering \& Materials Science, 334 Hinds Hall, Syracuse, NY 13244-1190

68. T. A. Todd, Idaho National Engineering and Environmental Laboratory, Building 637, MS-5218, Idaho Falls, ID 83415-5218

69. G. Vandegrift, Argonne National Laboratory, Building 205, 9700 South Cass Avenue, Argonne, IL 60439

70. J. H. Westsik, Pacific Northwest National Laboratory, P.O. Box 999, MS: K9-91, Richland, WA 99352

71. W. R. Wilmarth, Westinghouse Savannah River Company, P.O. Box 616, 773-42A, Room 153, Aiken, SC 29808

72. P. E. Woodall, U.S. Department of Energy, Idaho Operations Office, 750 DOE Place (MS: 1145), Idaho Falls, ID 83402

73. Tanks Focus Area Technical Team, c/o B. J. Williams, Pacific Northwest National Laboratory, P.O. Box 999, MSIN: K9-69, Richland, WA 99352

74. Tanks Focus Area Field Lead, c/o T. P. Pietrok, U.S. Department of Energy, Richland Operations Office, P.O. Box 550, MS: K8-50, Richland, WA 99352 